\title{
Middle-Upper Triassic stratigraphy and structure of the Alt Palància (eastern Iberian Chain): A multidisciplinary approach
}

F.Ortí' J.Guimerà ${ }^{*} \quad$ A.E. Götz ${ }^{3}$

'Departament de Mineralogia, Petrologia i Geologia aplicada, Facultat de

Ciències de la Terra, Universitat de Barcelona (UB)

C/ Martí Franquès s/n, 08028 Barcelona. Ortí E-mail: f.orti@ub.edu

${ }^{2}$ Geomodels Research Institute, Departament de Dinàmica de la Terra i de l'Oceà,

Facultat de Ciències de la Terra, Universitat de Barcelona (UB)

C/ Martí Franquès s/n, 08028 Barcelona. Guimerà E-mail: joan.guimera@ub.edu

${ }^{3}$ School of Earth and Environmental Sciences, University of Portsmouth

PO1 3QL Portsmouth, U.K. Götz E-mail: annette.goetz@port.ac.uk

${ }^{*}$ Corresponding author

A B S T R A C T

The present study provides new data of the Middle-Upper Triassic successions and their deformation in the eastern Iberian Chain, where contractional tectonics during the Cenozoic disrupted this Mediterranean type of Triassic rocks. The succession, divided into three Muschelkalk units, was studied in the Alt Palància area. In this area, both the lower and upper Muschelkalk consist of two main types of sub-units, those made up of carbonate and those of carbonate-marl alternation. The marked similarity observed between the evaporite units of the middle Muschelkalk and the Keuper hampers their unambiguous discrimination in the field. The integration of geological mapping, stratigraphic logging, palynological dating and gypsum isotope analysis should provide that: i) a change in the structural style, facies, and depositional thickness occurs across a SW to NE transect at both sides of the Espina-Espadà Fault, providing evidence for the extensional activity of this major structure; ii) palynological data assign Anisian age to the Röt facies and to the lower and the middle Muschelkalk units, and Ladinian to the upper Muschelkalk unit; iii) the $\delta^{34} \mathrm{~S}_{\mathrm{CDT}}$ and $\delta^{18} \mathrm{O}_{\text {SMOW }}$ values of gypsum are an useful proxy to discriminate between the middle Muschelkalk ( $\delta^{34} \mathrm{~S}$ : 15.6 to $17.8 \%$ ) and the Keuper $\left(\delta^{34} \mathrm{~S}: 14\right.$ to $15.5 \%$ ) units; and iv) the isotopic signature also helps to identify clayey-marly-gypsiferous outcrops made up of the two evaporite facies due to tectonic juxtaposition. These results confirm the Mediterranean type of Triassic rocks for the entire Alt Palància and other areas to the NE. This multidisciplinary approach has proved to be a robust method to study Triassic basins in Iberia and in other geological domains where the carbonate-evaporite successions have been greatly disrupted by tectonism.

KEYWORDS Triassic. Stratigraphy. Structural geology. Palynology. Isotopy. Iberian Chain.

\section{INTRODUCTION}

The Middle-Upper Triassic stratigraphy in western and central Europe is characterized by the 'Germanic type of
Triassic', which is comprised of an alternation of marine carbonates and marine-derived evaporites (Bernasconi et al., 2017; Lucas, 2017). Carbonate and evaporite units are very similar in facies and difficulties arise to distinguish

(C) Ortí, Guimerà, A.E., Götz, 2020 CC BY-SA 
these units when they have been affected by tectonism. Traditional confusions and controversies are recorded in the literature dealing with this specific problem (Soto et al., 2017).

Studies of the Triassic basins of Iberia provide good examples of these confusions (Boulouard and Viallard, 1981). However, identifying correctly the carbonate and evaporite units is a necessary step to more accurately delineate the paleogeographic distribution of the two first marine floodings in the westernmost part of the Neotethys realm during Anisian-Rhaetian times. Using subsurface data, Castillo Herrador (1974) documented for the first time the stratigraphic complexity of the Middle-Upper Triassic carbonate-evaporite alternation in NE of Iberia. From base to top, the complete succession involves the following units: Röt evaporites, lower Muschelkalk carbonates, middle Muschelkalk evaporites, upper Muschelkalk carbonates, Keuper evaporites, Norian-Rhaetian(?) carbonates (Imón Fm.), Rhaeto-Hettangian evaporites (Anhydrite Zone), and Hettangian-Sinemurian carbonates. Several Triassic basins, such as those in the Pyrenean, the Basque-Cantabrian, the Iberian and the Subbetic ranges have been severely disrupted by Alpine tectonism and Mesozoic-Cenozoic diapirism.

Studies of Middle Triassic-Lower Jurassic units in the basins of Iberia have addressed, for instance, the distinctions between lower and upper Muschelkalk carbonates and between the middle Muschelkalk and the Keuper evaporites established by Virgili $(1955,1958)$ in the Catalan Chain. However, the distinction between the Keuper and the Anhydrite Zone evaporites (Lécera Fm.) in the eastern Pyrenees has not been firmly established until recently (Salvany, 2017).

Other important aspects regarding the Middle-Upper Triassic remain unsolved and are under discussion. One of these aspects refers to the paleogeographic distribution of deposits during the first marine Triassic incursion in eastern Iberia. This has been recently addressed in an extensive revision by (Escudero-Mozo et al., 2015).

The present study analyzes the Middle-Upper Triassic succession in the eastern Iberian Chain, where the above-mentioned stratigraphic uncertainties occur. The study provides new cartographic, stratigraphic and structural observations, together with palynological dating of marl samples and isotope analysis of sulfate samples. It is proposed that this multidisciplinary approach can be applied to other Triassic basins of the Germanic-type facies in Iberia and, in general, to basins in other geological domains characterized by alternations of carbonate and evaporite units affected by tectonism.

\section{STRATIGRAPHIC SETTING}

Geological mapping and lithostratigraphic characterization of carbonate and evaporite deposits of the Middle-Upper Triassic successions in the eastern Iberian Chain have been addressed in earlier works dating back to the early $20^{\text {th }}$ century (Hahne, 1943; Brinkmann, 1948). First studies in the northern and central Valencian Country identified a single carbonate unit as Muschelkalk facies and assigned all the associated clayey-gypsiferous materials to the Keuper facies (Brinkmann, 1948; Dupuy de Lôme, 1959; Dupuy de Lôme and Sánchez Lozano, 1959; Hahne, 1930). The same approach was followed in some of the geological maps at 1:50,000 scale of this area edited by IGME MAGNA program in the seventies of the $20^{\text {th }}$ century (IGME, 1974d, 1975, 1978).

López-Gómez et al. (1998), Sopeña et al. (1983) and Virgili et al. (1977) assigned to the 'Mediterranean Triassic', the rocks in the València area of the eastern Iberian Chain in which the presence of the three Muschelkalk units was assumed, i.e. two carbonate units (lower Muschelkalk or M1 unit, and upper Muschelkalk or M3 unit) separated by a siliciclastic-evaporitic unit (middle Muschelkalk or M2 unit). Prior to the definition of the Mediterranean Triassic -and based on the work by Virgili (1955) in Catalonia- the three Muschelkalk units were also identified in the València area by other authors (de Lapparent and MontardestPentecote, 1957; Rambaud, 1962). In the explanation booklet of the geological maps at scale 1:50,000 of Chelva (IGME, 1973), Sagunto (IGME, 1974a) and Alcora (IGME, 1974b) the presence of these three Muschelkalk units is reported. However, they have been mapped as a single unit, and only an evaporitic unit attributed always to the Keuper has been mapped as a separate unit.

López-Gómez et al. (1998) distinguished the 'LevantineBalearic Triassic' in the coastal area of the eastern Iberian Chain. According to these authors, the three Muschelkalk units of the Mediterranean Triassic are represented in that area by a single carbonate Muschelkalk unit dated as late Anisian-Ladinian (Fig. 1).

Other studies in the eastern Iberian Chain led to a variety of interpretations of the Middle-Upper Triassic stratigraphy. Guimerà (1987) identified three Muschelkalk units in the Triassic succession of the Llucena outcrop, which is located to the north of the area addressed in the present study (Fig. 2A). Later, Jerez Mir (1996) distinguished up to five Muschelkalk units in the València area (the socalled "Betiberic Triassic"). Garay Martín (2001, 2005a) recognized three Muschelkalk units in the Calderona and the Espadà ridges (Fig. 2A). Ortí and Guimerà (2015) also identified three Muschelkalk units in the Alt Palància (Fig. 2A). Escudero-Mozo et al. (2015) have re-assigned the 
carbonates forming the Muschelkalk facies in the eastern Iberian Chain to the upper Muschelkalk unit and dated this carbonate unit as late Illyrian (latest Anisian)-Longobardian (late Ladinian). The newly defined unit by EscuderoMozo et al. (2015) extends throughout the Maestrat, the Calderona-Espadà, and most of the Alt Palància areas.

The confusion of the middle Muschelkalk by the Keuper facies in the eastern Iberian Chain has been documented by Boulouard and Viallard (1981) and Viallard (1973) in the Serranía de Cuenca, and by Doubinger et al. (1990) in the Cuenca to Manzanera area (Fig. 2A), amongst other authors.

Moreover, the lithostratigraphic terminology for the Middle Triassic in the eastern Iberian Chain is not consistent (Fig. 1). Initially, López-Gómez and Arche (1992) proposed the Landete, Mas, and Cañete formations and associated members. Later, the Middle Triassic Oronet, Azúebar, Cirat, and Pina de Montalgrao formations and associated members were introduced by Garay Martín (2001, 2005a, b) in the Calderona and Espadà ridges. However, Garay
Martín (2001, 2005a) did not find any correspondence between his members in the Oronet Formation and those previously defined in the Landete Formation by LópezGómez and Arche (1992).

In the study area of this paper (Fig. 2B), the available geological maps illustrate the uncertainty concerning the Middle-Upper Triassic stratigraphy. A single carbonate unit, identified as 'Muschelkalk facies', and a single clayeymarly-gypsiferous unit assigned to the 'Keuper facies' have been distinguished in the Jérica (639; IGME, 1977) and Manzanera (614; IGME, 1974c) maps. A similar interpretation has been adopted in the neighboring geological maps published by IGME in the 1973-1978 period (Segorbe, Alpuente, and Camarena de la Sierra maps; in IGME, 1974d, 1975, 1978, respectively).

\section{STRUCTURAL SETTING}

A generalized planation surface developed after the erosion of the Variscan orogenic belt (i.e. Termier and

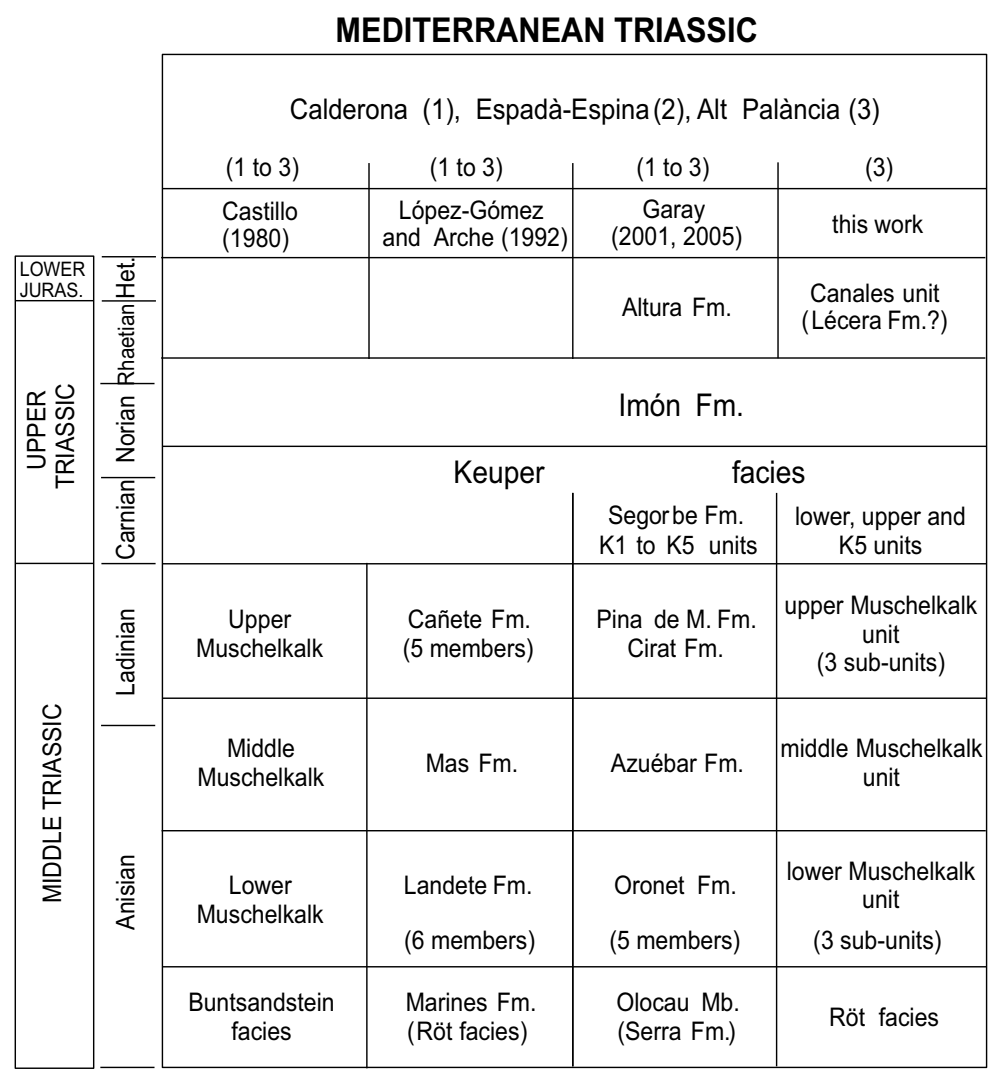

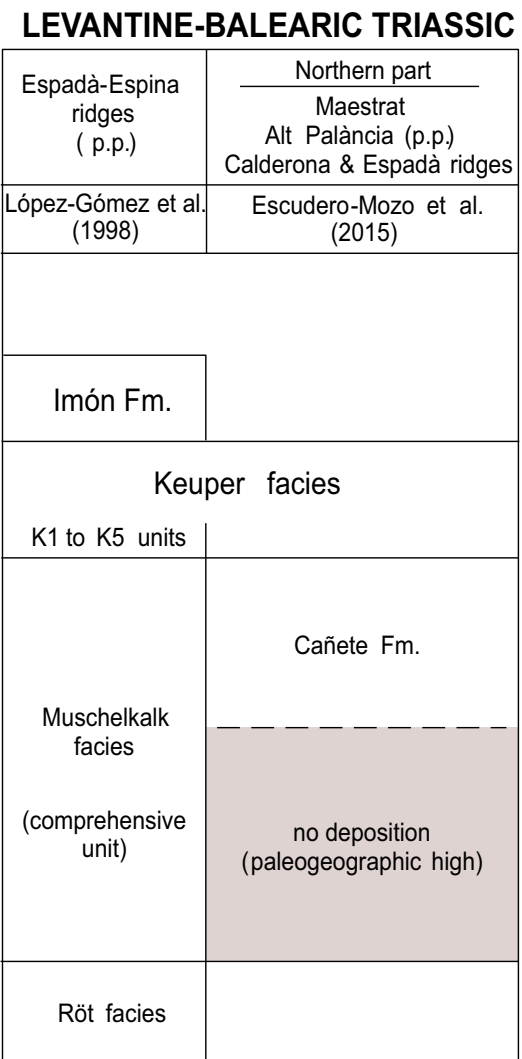

FIGURE 1. Stratigraphic framework of the Middle-Upper Triassic successions in the Mediterranean type of Triassic (Calderona ridge, Espadà-Espina ridge and Alt Palància area) and in the Levantine-Balearic type of Triassic compiled after several authors. Complete names of the formations: Altura Claystone and Gypsum Fm.; Azuébar sandy Marls, Lutites and Dolostones Fm.; Cañete Dolostone and Limestone Fm.; Cirat Dolostone Fm.; Imón Dolostone Fm.; Landete Dolostone Fm.; Lécera Gypsum, Anhydrite and Carbonate Fm.; Marines Clay, Silt, and Marl Fm.; Mas Clay, Marl and Gypsum Fm.; Oronet Dolostones Fm.; Pina de Montalgrao dolomitic Limestones Fm.; Segorbe gypsiferous Clays Fm. 
Termier, 1960). In the Iberian Chain it is preserved as a widespread unconformity (Álvaro et al., 1979; Salas et al., 2001) covered by continental and shallow marine rocks during the Late Permian, the Mesozoic and the Early Paleogene. Crustal extension was predominant since Late Permian, and generated rift-related sedimentary basins, bounded by normal faults. Periods dominated by rifting activity alternated with periods dominated by thermal subsidence. The main rifting periods were i) the Late Permian to Middle Triassic (Buntsandstein and lower and middle Muschelkalk facies), and ii) the Late Jurassic and Early Cretaceous (Nebot, 2016; Nebot and Guimerà, 2016a, b; Salas and Casas, 1993; Salas et al., 2001).

The Lower Triassic facies were bounded by highangle normal faults, most of them trending NW-SE but also NE-SW (Arche and López-Gómez, 1996;
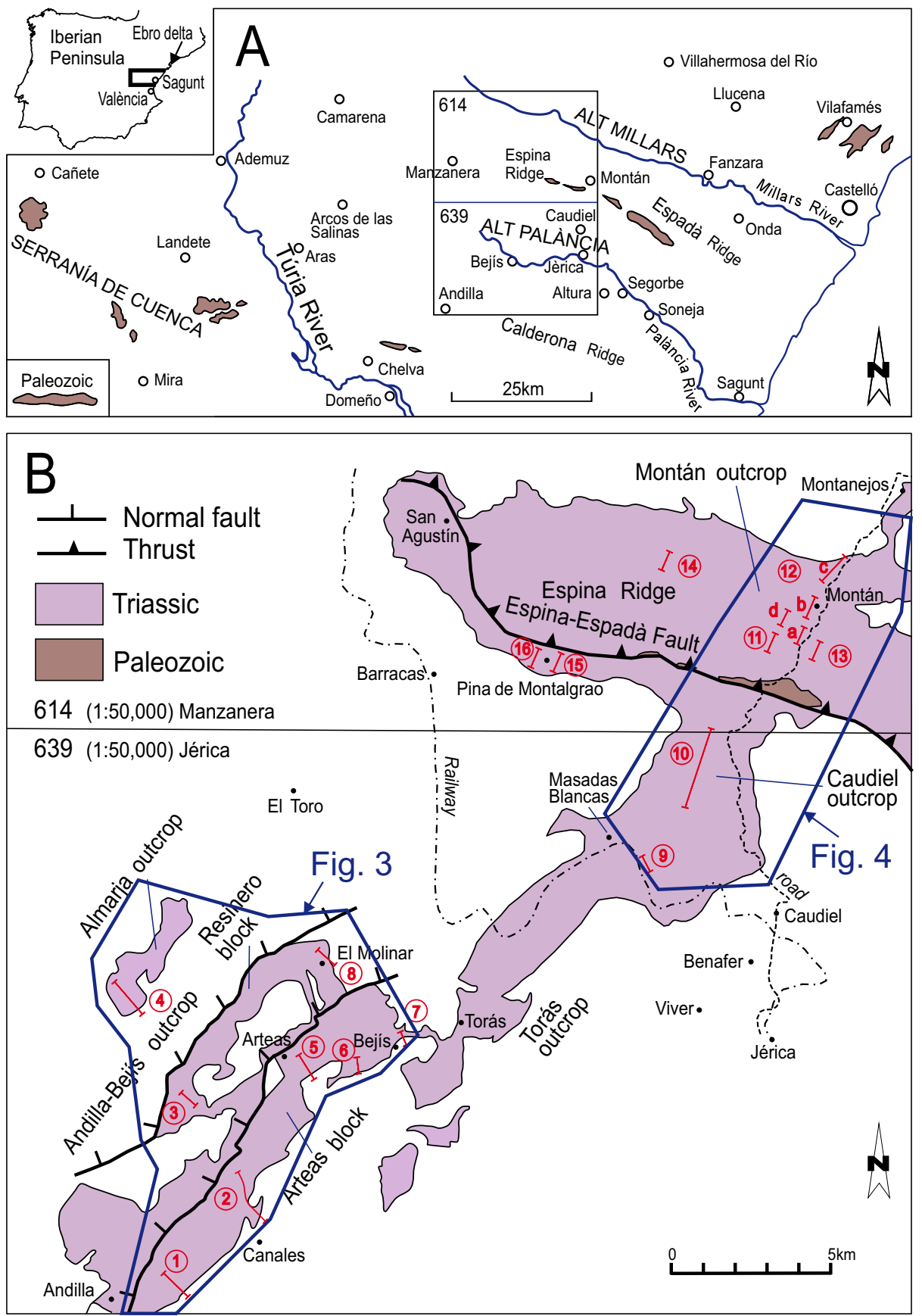

FIGURE 2. A) Location map of the study area. B) Distribution of the Triassic outcrops in the Jérica (639) and Manzanera (614) geological maps at scale 1:50,000. The position of the studied stratigraphic sections (S1 to S16) is shown. The structural blocks in the Andilla-Bejís, Almarja and Torás outcrops are highlighted. 
Guimerà et al., 2004; Salas and Casas, 1993), while listric extensional faults were dominant during the Late Jurassic-Early Cretaceous rifting period, striking mainly E-W but also NW-SE (Salas and Casas, 1993; Salas et al., 2001). As a result, a superposition of extensional faults of different geometries and orientations affect the Mesozoic rocks.

From Late Eocene to Early Miocene times, the study area experienced contraction and some Mesozoic extensional faults were inverted as reverse faults or thrusts (Salas et al., 2001). As the Mesozoic faults had different orientation, so did the contractional faults (Guimerà, 2018).

\section{MATERIALS AND METHODS}

The Triassic outcrops studied are Andilla-Bejís, Almarja, Torás, Caudiel, and Montán (Fig. 2B). They were mapped at 1:10,000 scale and geological cross-sections were constructed. Several Middle-Upper Triassic stratigraphic sections were documented (S1 to S16; Fig. 2B), in variable detail depending on the local exposure conditions (Appendix I). Samples were taken for petrographic studies, palynological dating and isotopic determination. Sample position was indicated in the stratigraphic sections as well as on the maps.

Mineralogical identification of sulfate minerals (gypsum, anhydrite, celestite) and carbonate minerals (calcite, dolomite) was done petrographically in large-sized thin sections $(5 \times 5 \mathrm{~cm})$. Lithofacies characterization of the calcium sulfate rocks (outcrop samples) was done using hand specimens.

\section{Palynological samples}

Due to the rare occurrence of ammonoids in the Muschelkalk units of the eastern Iberian Chain (PérezValera et al., 2016) and in the study area, an attempt to distinguish and to date them was done by means of palynological analyses of clayey, marly and carbonatic lithologies. In total 49 samples were collected, most of them in the lower and upper carbonate-marl alternations of the two carbonate Muschelkalk units. Thirty-one samples yielded positive results (Table 1).

Standard palynological processing techniques were used, including $\mathrm{HCl}(33 \%)$ and $\mathrm{HF}(73 \%)$ treatment for dissolution of carbonates and silicates, and saturated $\mathrm{ZnCl}_{2}$ solution $(\mathrm{D} \approx 2.2 \mathrm{~g} / \mathrm{ml})$ for density separation. Residues were sieved at $15 \mu \mathrm{m}$ mesh size. Slides were mounted in Eukitt, a commercial, resin-based mounting medium. Sedimentary organic matter was studied under a Leica DM2000 transmitted light microscope.

\section{Samples for isotope analysis}

In the present study, isotopes $\left(\delta^{34} \mathrm{~S}_{\mathrm{VCDT}}\right.$ and $\delta^{18} \mathrm{O}_{\mathrm{VSMOW}}$ values in \%o) of Middle-Upper Triassic gypsum samples were analyzed. Twenty-four samples are from our area of study. Another twenty-two samples from neighboring Triassic outcrops were also incorporated to the analysis (Table 2). All samples were identified as secondary gypsum, i.e. gypsum derived from the hydration of anhydrite rocks in the subsurface. Some of the samples were taken in selected stratigraphic sections, and others as single samples in the gypsiferous units. For better stratigraphic control, twelve pairs of samples were taken in relatively close position (decameters of distance) of the same gypsiferous unit but in different layers (listed in Table 2). Thus, the assignment of a sample either to the Keuper or to the middle Muschelkalk considered not only its own isotopic values but also i) those of the associated sample in the same unit and ii) the cartographic-stratigraphic criteria. The results were compared with available data from Triassic basins of Iberia, and with those of Bernasconi et al. (2017) from marine sulfates of Triassic basins in central and southern Europe.

The twenty-two additional gypsum samples studied for comparison are from the following Triassic outcrops in the eastern Iberian Chain (Fig. 2A): Soneja-Segorbe-Altura (Southern part of the Alt Palància); Villahermosa del Río (NW of the Llucena outcrop); Fanzara (Alt Millars); and Chelva (Domeño section; Pérez-López et al., 1996).

For the isotope analysis, each sample was dissolved in distilled water, acidified to $\mathrm{pH} 3$ adding $\mathrm{HCl}$ and then reprecipitated as barium sulfate by means of a solution of $\mathrm{BaCl}_{2}$. Sulphur and oxygen isotope compositions were analyzed by the on-line method. The $\delta^{34} \mathrm{~S}_{\mathrm{V}-\mathrm{CDT}}$ was determined with a Carlo Erba 1108 Elemental Analyzer and the $\delta^{18} \mathrm{O}_{\text {-SMow }}$ with a TC-EA unit, both coupled to an IRMS ThermoFisher Delta Plus XP at the Stable Isotope Laboratory of the CCiTUB (Universitat de Barcelona). The obtained $\delta^{34} \mathrm{~S}$ and $\delta^{18} \mathrm{O}$ values are reported in $\%$ relative to the Vienna Canyon Diablo Troilite (V-CDT) standard for Sulfur and to the Vienna Standard Mean Ocean Water (V-SMOW) standard for oxygen. The analytical error

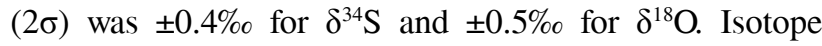
compositions obtained by the Standard IAEA NBS-127 were of $20.3 \%$ for $\delta^{34} \mathrm{~S}$, and of $9.3 \%$ for $\delta^{18} \mathrm{O}$. Isotope compositions obtained for $\delta^{34} \mathrm{~S}$ by the Standard IAEA SO-5 were of $0.5 \%$ and by the Standard IAEA SO-6 were of $-34.1 \%$.

\section{Terminology and assumptions made in the study}

i) The traditional terms 'lower Muschelkalk unit' (M1), 'middle Muschelkalk unit' (M2), and 'upper Muschelkalk unit' (M3) are used for the Landete Fm., the Mas Fm., 
and the Cañete Fm. of López-Gómez and Arche (1992), respectively (Fig. 1). These informal terms have been often used in the study area (Castillo, 1980; cited in Garay Martín, 2001) and in adjacent regions (IGME, 1985a, b).

ii) No units are distinguished within the clayey-marlygypsiferous middle Muschelkalk facies (Mas Fm. of López-Gómez and Arche, 1992).

iii) The Keuper facies is subdivided in a 'lower grey unit', an 'upper red unit', and a top K5 unit. The Keuper succession in the study area is relatively simple compared to that in the València area (K1 to K5 units of the 'Valencia Keuper Group'; Ortí, 1974) and of the subsurface in La Mancha area (Suárez, 2007).

iv) The original terms 'Imón Dolostones Formation' (Rhaetian age; Goy et al., 1976), and 'Lécera Gypsum, Anhydrite and Carbonate Formation' (Rhaetian-Hettangian age; Gómez and Goy, 1998) are used here for the youngest Triassic unit and the oldest Jurassic unit, respectively.

v) The Lécera Fm. is not identified with certainty in the study area as an evaporitic unit. Locally, however, the 'Canales red Claystone unit' (informal term in Ortí and Guimerà, 2015) takes the stratigraphic position of the Lécera Fm.

\section{RESULTS}

\section{Stratigraphic framework and correlations}

Two types of sub-units, i.e. 'carbonate sub-unit' and 'carbonate-marl alternations', were identified in the exposed carbonatic Muschelkalk. The carbonate sub-unit includes bedded dolostones and rarely limestones, in which marl intercalations are absent. The carbonate-marl alternations consist of carbonatic beds in irregular alternation with grey marly beds, which may underly ('lower alternation') and/or overly ('upper alternation') the carbonate sub-unit.

The possible equivalence of these sub-units with the Lower Muschelkalk members defined by other authors is as follows (Fig. 1): The lower carbonate-marl alternation, which is present in all the studied outcrops, is equivalent to the Alcalà Member (17.5m thick, at the base of the Oronet Fm.) defined by Garay Martín (2001) in the CalderonaEspadà area and, most likely, to the Serra Member $(13 \mathrm{~m}$ thick) of López-Gómez and Arche (1992). The carbonate sub-unit is equivalent to the assemblage of the Banyet, Sagunt, and Pla de les Llomes members of Garay Martín (2001), and most likely to the assemblage of the San Martín, Mal Paso, Olocau and Peña Rubia members of López-Gómez and Arche (1992). The upper carbonate- marl alternation, however, has not a clear equivalent in the literature. It is only present in one of the studied sections (S10, see below; see also Appendix I), while in the other sections a white dolomicritic assemblage forms the top of the carbonate sub-unit. This top dolomicritic assemblage is equivalent to the El Sierro Member (25m thick) of Garay Martín (2001). López-Gómez and Arche (1992) described the Beamud Member as formed by a carbonate-marl alternation, at the top of the Landete Formation in sections of Cuenca. We assume that the upper alternation of the present study is equivalent to the Beamud Member.

An accurate correlation of the middle Muschelkalk with the units recently defined in the Triassic Catalan basin by Ortí et al. (2018) was not possible.

Regarding the upper Muschelkalk, the lower alternation corresponds to the 'basal alternation of dolostones and marls' member of the Cirat Formation of Garay Martín (2001) (Fig. 1). According to Garay Martín (2001), the thickness of this alternation ranges from 4 to $8 \mathrm{~m}$ in the Calderona-Espadà area, although it is often very thin or even lacking due to tectonism. The carbonate sub-unit is equivalent to the assemblage of the Gorgocil, Henarejos, Huélamo and Valacloche members of the Cañete Fm. of López-Gómez and Arche (1992). The upper alternation is equivalent to the Royuela Formation of Pérez-Arlucea and Sopeña (1985), to the Pina de Montalgrao Fm. of Garay Martín (2001) and, most likely, to the Moya Mb. (Cañete Fm.) of López-Gómez and Arche (1992).

We assume that the Canales red Claystone unit may be a non-evaporitic lateral stratigraphic equivalent of the Lécera Formation of Gómez et al. (2007) as proposed by Ortí and Guimerà (2015).

\section{Mapping and structural results}

Brief descriptions of the studied outcrops (Fig. 2B) are given below, and further information and comments of the stratigraphic sections are compiled in Appendix I. Geological maps of the Andilla-Bejís-Almarja and the Montán-Caudiel outcrops are shown in Figure 3 and Figure 4 , respectively.

The Andilla-Bejís outcrop is almost $14 \mathrm{~km}$ long in a SW-NE direction (Figs. 2B; 3). Two kilometer-scale normal faults (NE-SW-striking, NW-dipping) affect the Triassic and Jurassic rocks, generating SE-tilted blocks, i.e. the Arteas and the Resinero blocks (Fig. 2B). An angular unconformity separates the Hettangian (Lower Jurassic) Cortes de Tajuña Fm. from the underlying Triassic rocks. The Triassic displays a larger tilting angle than that of the Jurassic rocks. The Triassic rocks are partially eroded under the Cortes de Tajuña Fm. to the NW of the tilted blocks. 
TABLE 1. Palynological results. Projection UTM, datum ED50

\begin{tabular}{|c|c|c|c|c|c|c|c|}
\hline Outcrop & Section & Stratigraphic unit/sub-unit & Sample & Lithology & Age assignment & \multicolumn{2}{|c|}{ X, Y Coordinates } \\
\hline Almarja & S4 & lower alternation, Lw. Musch. & 236 & marly carbonate & Anisian (Bithynian/Pelsonian) & 688592 & 4423712 \\
\hline Almarja & S4 & base of the Md. Musch. & 244 & grey dolomitic marl & Anisian (undivided) & 688650 & 4423679 \\
\hline Andilla & S1 & Middle Muschelkalk & 211 & grey marly limestone & Anisian (Aegean/Bithynian) & 688891 & 4413057 \\
\hline Andilla & s1 & Middle Muschelkalk & 212 & grey marly limestone & Anisian (Illyrian) & 689118 & 4412914 \\
\hline Andilla & S2 & base of the Md. Musch. & 215 & marly limestone & Anisian (Bithyniasn/Pelsonian) & 691138 & 4416025 \\
\hline Andilla & $\mathrm{S} 2$ & Middle Muschelkalk & 216 & grey carbonate & Anisian (Illyrian) & 691182 & 4415968 \\
\hline Andilla & S2 & upper alternation, Up. Musch. & 214 & light marly limestones & Ladinian (Fassanian?) & 691452 & 4415817 \\
\hline Caudiel & $\mathrm{S} 10$ & upper alternation, Lw. Musch. & 218 & grey marly limestone & Anisian (Bithynian/Pelsonian) & 691182 & 4415968 \\
\hline Caudiel & $\mathrm{S} 10$ & upper alternation, Lw. Musch. & 219 & grey marly limestone & Anisian (Bithynian/Pelsonian) & 705872 & 4427597 \\
\hline Caudiel & $\mathrm{S} 10$ & upper alternation, Lw. Musch. & 221 & grey marly limestone & Anisian (Bithynian/Pelsonian) & 705855 & 4427603 \\
\hline Caudiel & s9 & upper alternation, Up. Musch. & 198 & grey marl & Ladinian (Fassanian?) & 703338 & 4426784 \\
\hline Caudiel & - & upper alternation, Lw. Musch. & 291 & grey marl & Anisian (undivided) & 705015 & 4427695 \\
\hline Bejís & S6 & lower alternation, Lw. Musch. & 201 & grey marl & Anisian (undivided) & 694808 & 4419890 \\
\hline Molinar (Bejís) & S8 & Röt & 241 & dark claystone & Anisian (undivided) & 693472 & 4423593 \\
\hline Molinar (Bejís) & S8 & lower alternation, Lw. Musch. & 242 & grey claystone & Anisian (undivided) & 693527 & 4423717 \\
\hline Molinar (Bejís) & S8 & lower alternation, Lw. Musch. & 243 & grey claystone & Anisian (undivided) & 693471 & 4423605 \\
\hline Montán & $\mathrm{S} 12 \mathrm{a}$ & lower alternation, Lw. Musch. & 273 & grey claystone & Anisian (undivided) & 708299 & 4433569 \\
\hline Montán & $\mathrm{S} 12 \mathrm{a}$ & upper alternation, Up. Musch. & 196 & grey marl & Ladinian (Fassanian?) & 708407 & 4433758 \\
\hline Montán & $\mathrm{S} 12 \mathrm{a}$ & upper alternation, Up. Musch. & 231 & grey marly limestone & Ladinian (Fassanian?) & 708402 & 4433740 \\
\hline Montán & $\mathrm{S} 12 \mathrm{a}$ & upper alternation, Up. Musch. & 233 & grey marly limestone & Ladinian (Fassanian?) & 708309 & 4433910 \\
\hline Montán & S12d & Middle Muschelkalk & 277 & green claystone & Anisian (Illyrian) & 708192 & 4434781 \\
\hline Montán & S12d & lower alternation, Up. Musch. & 252 & grey marl & Ladinian (undivided) & 708271 & 4434774 \\
\hline Montán & S12d & lower alternation, Up. Musch. & 253 & grey marl & Ladinian (undivided) & 708278 & 4434775 \\
\hline Montán & S12d & lower alternation, Up. Musch. & 254 & grey marl & Ladinian (undivided) & 708322 & 4434799 \\
\hline Montán & S12d & lower alternation, Up. Musch. & 255 & grey marl & Ladinian (undivided) & 708322 & 4434826 \\
\hline Montán & $\mathrm{S} 12 \mathrm{~b}$ & upper alternation, Up. Musch. & 234 & green marly limestone & Ladinian (Fassanian?) & 709493 & 4435863 \\
\hline Montán & S11 & lower alternation, Lw. Musch. & 248 & green claystone & Anisian (undivided) & 707676 & 4433841 \\
\hline Montán & S11 & lower alternation, Lw. Musch. & 249 & dark claystone & Anisian (undivided) & 707677 & 4433829 \\
\hline Montán & S11 & lower alternation, Lw. Musch. & 250 & green claystone & Anisian (undivided) & 707676 & 4433839 \\
\hline Pina de Montalgrao & S15 & lower alternation, Up. Musch. & 245 & green claystone & Ladinian (undivided) & 699550 & 4433017 \\
\hline Pina de Montalgrao & $\mathrm{S} 15$ & lower alternation, Up. Musch. & 246 & light grey claystone & Ladinian (undivided) & 699556 & 4433030 \\
\hline
\end{tabular}

The Muschelkalk units often show periclinal terminations of folds at both ends of these two blocks (Fig. 3). The geological section crosscutting this outcrop is shown in Figure $5\left(\mathrm{~A}^{-} \mathrm{A}^{\prime}\right)$. The stratigraphic section studied (S1 to S8) are shown in Figure 6. The thickest and most complete Triassic succession is at the southwestern end of the Arteas block between the Canales and Andilla villages (S1, Fig. 2B, first cited in Ortí and Gimerà, 2015) (Appendix I). The Triassic succession pinches out laterally in a NE direction in the Arteas block. Within the two blocks of this outcrop, only the $\mathrm{S} 1$ section preserves a complete Middle-Upper Triassic succession. In the other sections, partial erosion occurs under the unconformable Jurassic cover (Fig. 6).

The Almarja outcrop is located at the NW corner of the study area, at the core of a NE-SW anticline involving both Triassic and Jurassic rocks (Fig. 3). It is formed by SE-tilted Triassic rocks, bounded by the Lower Jurassic unconformity. Section S4 was obtained from this outcrop. Other smaller Triassic outcrops are located in the central Jérica map near the village of Torás (Fig. 2B).

The Montán and Caudiel outcrops extend in a NESW orientation from the Montán village in the NE to the Caudiel-Masadas Blancas line in the SW (Figs. 2B; 4). They are cross-cut by the Espina-Espadà Fault, striking WNWESE and dipping NNE. Paleozoic rocks belonging to the Variscan basement crop out in its hanging-wall, which is unconformably covered by Upper Permian and Buntsandstein
(Lower Triassic) red-beds, followed by Muschelkalk and Keuper facies. Mostly Muschelkalk and Keuper facies crop out in its foot-wall, which only contains two tiny and isolated outcrops of Paleozoic and Buntsandstein rocks. A geological section cross-cutting these outcrops is shown in Figure 5 (BB'). The stratigraphic sections S9, S10, S11, S12 (Fig. 7) and S13 to S16 (Fig. 8) were logged.

The Espina-Espadà Fault is currently a reverse fault, although it is interpreted as a Triassic normal fault inverted during the Cenozoic contraction. This interpretation is based on the $1080 \mathrm{~m}$ thick Permian and Buntsandstein redbeds found in its hanging-wall (Fig. 5, B-B'), indicating deposition of these sediments in a basin with very high rates of subsidence. Extensional faults cutting the Triassic rocks were recognized in both the hanging-wall and the foot-wall of the Espina-Espadà Fault.

Cenozoic thrusts and folds involve rocks in the hangingwall and the foot-wall of the Espina-Espadà Fault. In the foot-wall, these structures are located near the fault, being interpreted as the result of the deformation related to its reverse inversion. To the south, a dome-shaped, gently dipping anticline is found NW of Caudiel. A southverging imbricate thrust-system, detached at the middle Muschelkalk level, is found in the hanging-wall of the Espina-Espadà Fault (Figs. 4; 5B).

The Montán composite section (S12), studied mainly along the Caudiel-Montanejos road, is representative of 


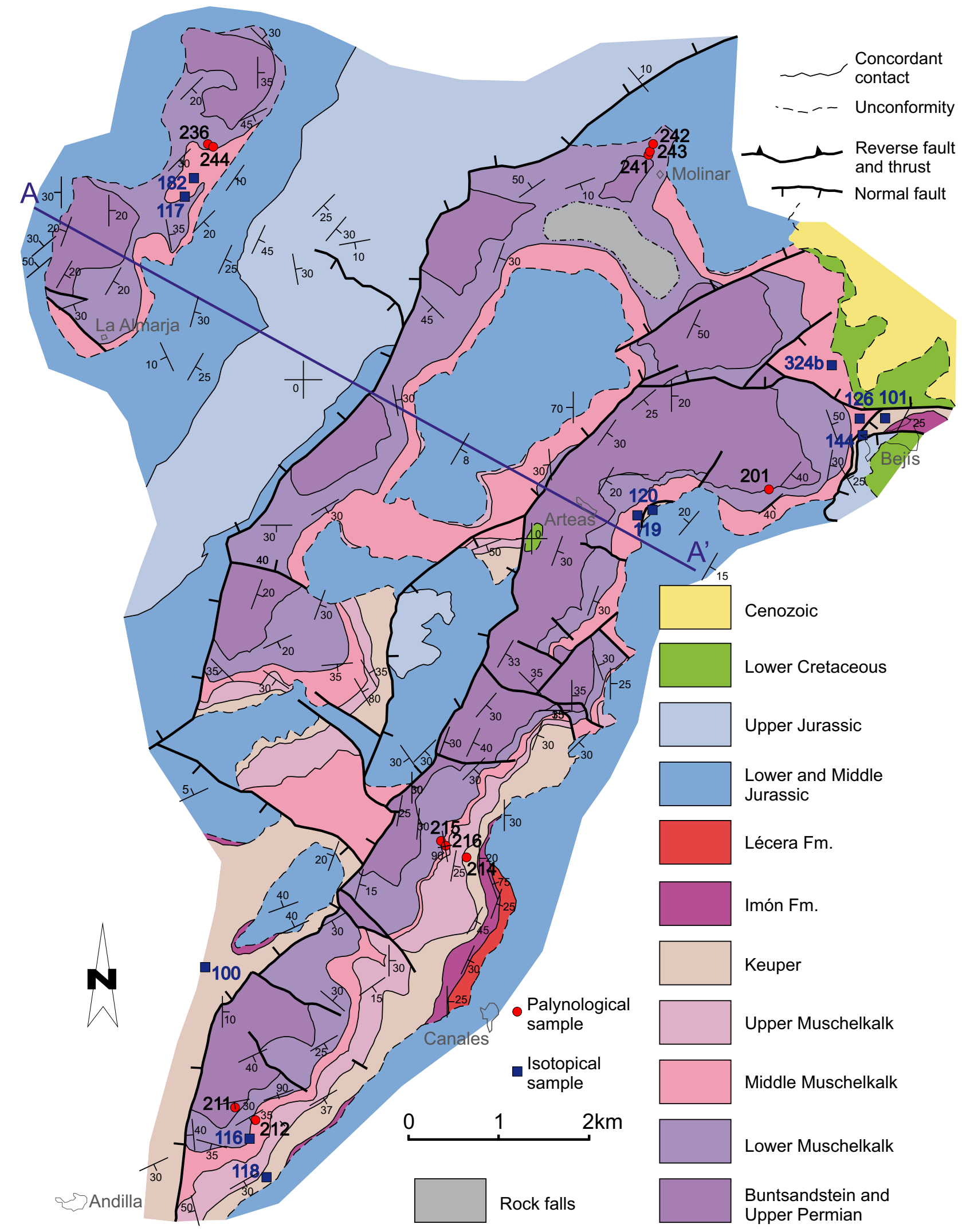

FIGURE 3. Geological map of the Andilla-Bejís and the Almarja outcrops exposing Triassic (see Fig. 2 for location). 


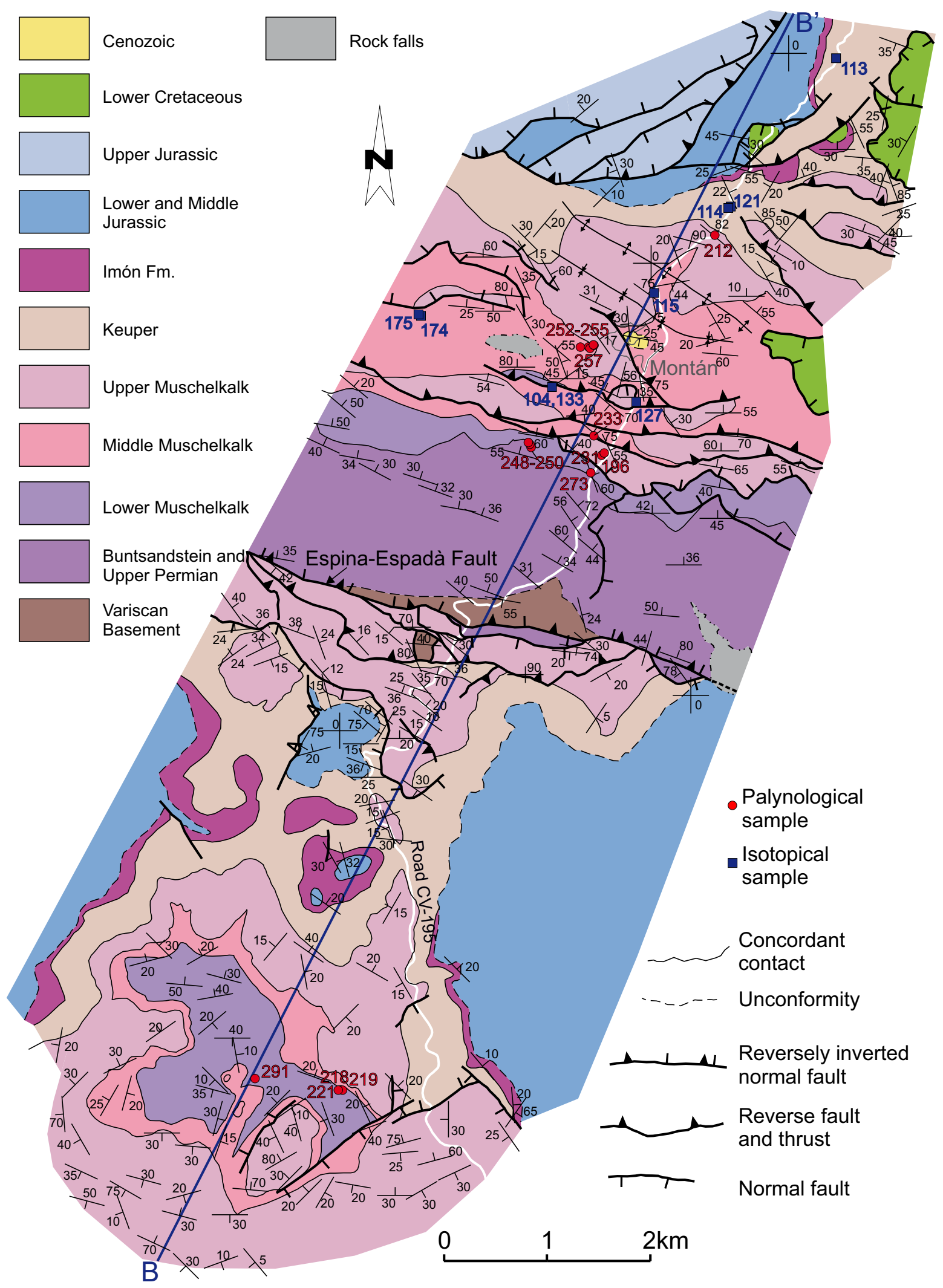

FIGURE 4. Geological map of the Montán and Caudiel outcrops exposing Triassic (see Fig. 2 for location). 
TABLE 2. Isotopic results. Pairs of samples taken in relatively close position in the same units: Keuper: 103-134, 114-121, 112-136, 140-141, 122169, 149-153; middle Muschelkalk: 102-125, 104-133, 148-170, 164-165; and pairs interpreted as tectonic juxtaposition of Keuper and middle Muschelkalk gypsiferous materials: 120-119, 101-126. (a): Ortí et al. (2014); (b): Ortí et al. (2018). Projection UTM, datum ED50, Zone 30

\begin{tabular}{|c|c|c|c|c|c|c|c|c|}
\hline \multirow{2}{*}{$\begin{array}{l}\text { Outcrop } \\
\text { STUDY AREA, ALT PALANCIA }\end{array}$} & \multirow[t]{2}{*}{ Section/Locality } & \multirow[t]{2}{*}{ Stratigraphic unit } & \multirow[t]{2}{*}{ Sample } & \multirow[t]{2}{*}{ Gypsum Lithofacies } & \multirow[t]{2}{*}{$\delta^{34} \mathrm{~S}(\% 0)$} & \multirow[t]{2}{*}{$\delta^{18} \mathrm{O}(\%)$} & \multicolumn{2}{|c|}{$\mathrm{X}, \mathrm{Y}$ Coordinates } \\
\hline & & & & & & & & \\
\hline Almarja & S4 & Middle Muschelkalk & 117 (YsAt-18) & dark laminated & 15.6 & 16.7 & 688288 & 4422950 \\
\hline Almarja & S5 & Middle Muschelkalk & 182 (YsAt-27) & dark laminated & 16.4 & 18.1 & 688446 & 4423296 \\
\hline Andilla & S1 & Keuper & 118 (YsAt-15) & white nodular & 14.4 & 16.2 & 689233 & 4412209 \\
\hline Andilla & S1 & Middle Muschelkalk & 116 (YsAt-14) & nodular & 17.4 & 15.6 & 689009 & 4412633 \\
\hline Andilla & Vihuela & Keuper (K5) & 100 (ZA-Anh.) & white laminated & 14.3 & 11.5 & 688552 & 4414536 \\
\hline Bejís & S5 & Keuper & 120 (YsAt-17) & dark nodular & 14.4 & 15.6 & 693542 & 4419564 \\
\hline Bejís & S5 & Middle Muschelkalk & 119 (YsAt-16) & laminated & 16.3 & 14.6 & 693376 & 4419514 \\
\hline Bejis & S7 & Keuper & $101(\mathrm{Bj}-1)$ & dark laminated & 14.3 & 16.4 & 695956 & 4420617 \\
\hline Bejis & S7 & Middle Muschelkalk & $126(\mathrm{Bj}-2)$ & massive-nodular & 15.8 & 12.8 & 695819 & 4420623 \\
\hline Bejis & Bejís castle & Keuper & 144 (YsAt-22) & white nodular & 14.2 & 15.3 & 695749 & 4420169 \\
\hline Bejis & Light factory & Middle Muschelkalk & $324 \mathrm{~b}$ (YsAt-28) & grey laminated & 17.1 & 15.5 & 695507 & 4421370 \\
\hline Torás & road & Middle Muschelkalk & 102 (To-1) & dark laminated & 16.6 & 14.1 & 698628 & 4422033 \\
\hline Torás & road & Middle Muschelkalk & 125 (Тo-2) & dark laminated & 15.8 & 17.4 & 698592 & 4421988 \\
\hline Caudiel & Mas Noguera & Keuper (K5) & 103 (YP.ZA-1) & grey laminated & 14.0 & 11.8 & 703302 & 4432189 \\
\hline Caudiel & Mas Noguera & Keuper (K5) & 134 (YP.ZA-2) & grey laminated & 14.1 & 12.4 & 703779 & 4431811 \\
\hline Montán & Montanejos & Keuper & 113 (YsAt-10) & dark laminated & 15.5 & 16.3 & 710639 & 4437495 \\
\hline Montán & $12 \mathrm{c}$ & Lower Keuper & 114 (YsAt-114) & white laminated-nodular & 14.0 & 14.8 & 709597 & 4436050 \\
\hline Montán & $12 \mathrm{c}$ & Upper Keuper & 121 (YsAt-12) & white nodular & 14.2 & 16.5 & 709608 & 4436071 \\
\hline Montán & $12 b$ & Middle Muschelkalk & 115 (YsAt-13) & massive & 16.7 & 13.2 & 708815 & 4435263 \\
\hline Montán & $12 d$ & Middle Muschelkalk & 104 (M.MN-1) & white laminated-banded & 16.5 & 16.1 & 707883 & 4434344 \\
\hline Montán & $12 \mathrm{~d}$ & Middle Muschelkalk & 133 (M.MN-2) & grey laminated-banded & 16.3 & 15.9 & 707883 & 4434344 \\
\hline Montán & $12 a$ & Middle Muschelkalk & $127(\mathrm{MN}-1)$ & grey laminated & 16.1 & 13.5 & 708711 & 4434243 \\
\hline Montán & Fuente la R. track & Middle Muschelkalk & 174 (YsAt-23) & grey laminated & 17.8 & 15.7 & 706598 & 4435113 \\
\hline Montán & Fuente la R. road & Middle Muschelkalk & 175 (YsAt-24) & dark laminated & 17.2 & 18.0 & 706579 & 4435123 \\
\hline \multicolumn{9}{|l|}{ OTHER AREAS, ALT PALANCIA } \\
\hline Soneja quarry, active & quarry wall & Keuper & 112 (YsAtP-1) & white laminated & 13.3 & 10.7 & 720559 & 4408505 \\
\hline Soneja quarry, active & quarry wall & Keuper & 136 (YsAtP-2) & wite laminated & 13.9 & 10.4 & 720228 & 4409822 \\
\hline Sot de Ferrer quarry, inactive & quarry wall & Middle Muschelkalk & 171 (YsAt-5) & white massive & 16.4 & 16.1 & 721027 & 4409562 \\
\hline Villatorcas & road & Keuper & 140 (YsAt-3) & dark laminated & 14.5 & 17.0 & 718084 & 4411204 \\
\hline Villatorcas & road & Keuper & 141 (YsAt-4) & dark laminated & 14.5 & 16.9 & 718194 & 4411293 \\
\hline Segorbe & & Middle Muschelkalk & 137 (YsAt-6) & grey laminated & 16.7 & 15.5 & 713769 & 4414255 \\
\hline Altura-C. Santa road & road & Middle Muschelkalk & 138 (YsAt-7) & grey laminated & 15.7 & 16.5 & 711029 & 4413466 \\
\hline Altura, church road & road & Keuper & 139 (YsAt-8) & grey massive & 15.2 & 16.1 & 710713 & 4414070 \\
\hline \multicolumn{9}{|l|}{ OTHER OUTCROPS } \\
\hline Villahermosa del Río & Algepsar quarry & Keuper & $122($ YsVII-1) & white massive & 14.4 & 15.1 & 724684 & 4451147 \\
\hline Villahermosa del Río & Algepsar quarry & Keuper & $147($ YsVII-2) & white laminated & 14.6 & 13.6 & 724449 & 4451218 \\
\hline Villahermosa del Río & Algepsar quarry & Keuper & 169 (Ys.VII-3) & white laminated & 15.3 & 14.8 & 724449 & 4451218 \\
\hline Villahermosa del Río & collado & Middle Muschelkalk & 148 (YsVill-4) & dark porphyr. laminated & 16.7 & 17.8 & 724684 & 4450123 \\
\hline Villahermosa del Río & collado & Middle Muschelkalk & 170 (Ys.VII-5) & dark porphyr. laminated & 16.2 & 14.7 & 724606 & 4450148 \\
\hline Chelva & Alcotas creek & Keuper & 149 (Ys.Ch-1) & dark laminated & 15.2 & 15.4 & 673209 & 4403128 \\
\hline Chelva & Alcotas creek & Keuper & 153 (Ys.Ch-2) & pink massive & 15.6 & 17.3 & 673223 & 4403135 \\
\hline Chelva & Ahillas road & Keuper & 150 (Ys.Ch-3) & pink nodular & 14.4 & 15.0 & 672001 & 4403768 \\
\hline Chelva & Ahillas road & Middle Muschelkalk & 154 (Ys.Ch-4) & laminated & 16.1 & 15.5 & 672028 & 4403791 \\
\hline Chelva & Domeño section & Keuper (K5) & 151 (Ys.Ch-5) & white massive & 15.0 & 11.5 & 676861 & 4398238 \\
\hline Chelva & Domeño section & Keuper (K5) & 155 (Ys.Ch-6) & white laminated & 15.5 & 17.9 & 676850 & 4398222 \\
\hline Chelva & Domeño section & Keuper (K1) & 152 (YsCh.-7) & dark laminated & 15.5 & 13.7 & 676840 & 4398206 \\
\hline Fanzara & road & Middle Muschelkalk & 164 (Ys.At-20) & dark laminated & 16.6 & 16.9 & 728819 & 4431987 \\
\hline Fanzara & road & Middle Muschelkalk & 165 (YsAt-21) & grey, crystalline massive & 16.2 & 18.4 & 728819 & 4431987 \\
\hline \multicolumn{9}{|l|}{ OTHER BASINS (IBERIA) } \\
\hline \multirow[t]{2}{*}{ Betic basin (Ext. Z.) (a) } & & Keuper & 12 samples & & 13.8 to 15.6 & 10.0 to 16.9 & & \\
\hline & & Middle Muschelkalk & 2 samples & & $16.4,16.6$ & $13.5,11.5$ & & \\
\hline \multirow{2}{*}{ Catalan Basin (b) } & & Keuper & 16 samples & & 14.2 to 15.4 & 11.3 to 16.6 & & \\
\hline & & Middle Muschelkalk & 38 samples & & 16.5 to 18.7 & 10.3 to 16.5 & & \\
\hline Maestrat Basin (b) & & Middle Muschelkalk & 4 samples & & 17.3 to 17.5 & 12.1 to 13.0 & & \\
\hline
\end{tabular}

the complex Middle-Upper Triassic succession in the Montán outcrop (Fig. 7). To the south, the succession rests sharply tilted in contact with the Buntsandstein rocks, but several faults and thrusts disturb or repeat it, hindering the stratigraphic correlation towards the north. In the present study, this composite section was subdivided into three partial sections along the road (S12a, S12b, S12c), and a fourth partial section located close to the Montán village (S12d; Fig. 7; Appendix I).

\section{Palynological data}

The palynological assemblages identified in this study for each stratigraphic unit are characterized by the following key taxa, and ages were assigned applying the palynostratigraphic zonation scheme of Heunisch (1999), recently adapted by Heunisch (in press) to the previous Triassic zonations established in the Germanic realm by van Buggenum (1985), Brugman et al. (1988) and Holshuijsen (1987):

Aegean/Bithynian (early Anisian): Densoisporites nejburgii, Illinites kosankei, Voltziaceaesporites heteromorphus, Triadispora spp.

Bithynian/Pelsonian (middle

Anisian): Cristianisporites triangulates, Stellapollenites thiergartii, Tsugaepollenites oriens, Illinites kosankei, Voltziaceaesporites heteromorphus, Triadispora spp.

Illyrian (late Anisian): Stellapollenites thiergartii, Microcachryidites spp., Illinites chitonoides, Triadispora spp. 
Fassanian (early Ladinian): Kuglerina meieri, Protodiploxypinus gracilis, Podosporites amicus, Illinites chitonoides, Institisporites sp.

Ladinian (undivided): Kuglerina meieri, Illinites chitonoides, Protodiploxypinus gracilis, Aratrisposites sp.

Carnian (undivided): Camerosporites secatus, Triadispora verrucata, Patinosporites densus.

In the Triassic Germanic basin, and according to the palynological assemblages, the Lower Muschelkalk, the Middle Muschelkalk, and the lower part of the Upper Muschelkalk are Anisian, while the middle and upper parts of the Upper Muschelkalk and the Lower Keuper (Lettenkohle) are Ladinian in age.

The main results of the palynological study of the Alt Palància area are as follows (Table 1):

i) One sample in the Röt facies (section S8) yielded a palynological assemblage of Anisian age.

ii) In the lower Muschelkalk unit, the assemblages were as follows: i) all samples of the lower carbonate-marl alternation yielded either Anisian or early Anisian (Aegean/ Bithynian) assemblages (sections S1, S6, S8, S11); ii) the samples of the carbonate sub-unit yielded Anisian assemblages (sections S12a, S12b) and iii) the samples of the upper carbonate-marl alternation yielded middle Anisian (Bithynian-Pelsonian) assemblages (section S10).

iii) The samples of the middle Muschelkalk facies yielded middle-late Anisian (mainly Illyrian) assemblages (sections S1, S2, S4, S12d).

iv) In the upper Muschelkalk unit, the assemblages were as follows: i) all samples of the lower carbonatemarl alternation yielded Ladinian assemblages (sections $\mathrm{S} 12 \mathrm{~d}, \mathrm{~S} 15)$; ii) all samples of the upper carbonate-marl alternation yielded early Ladinian (Fassanian) assemblages (sections S2, S9, S12a, S12b) and iii) no specimens of Infernopollenites were identified in the palynological assemblages of the Ladinian (characterized by Kuglerina meieri), hindering clear evidence of the Longobardian stage; thus, all samples assigned to the Ladinian most likely represent the Fassanian stage.

v) No productive samples were obtained from clayeymarly-gypsiferous lithologies expected to correspond to the Keuper facies.

For the lower and upper Muschelkalk units, these palynological results are generally consistent with the expected stratigraphic assignments based on the previous cartographic-stratigraphic survey. However, in the Montán outcrop (sections S11 to S16) they are crucial to infer the existence of faults and thrusts, and to correctly identify each of the carbonate Muschelkalk units, including their respective carbonate-marl alternations (Figs. 7; 8).

Palynological dating of the Triassic successions in the SE Iberian Chain (Cuenca-Teruel-Valencia) done by Doubinger et al. (1990) dated the Middle-Upper Triassic successions in this area as follows: i) the Röt facies was assigned to the Anisian; ii) no microflora was found in the lower Muschelkalk unit (Landete Fm.), and this unit was assigned to the Anisian on the basis of stratigraphic correlation with other domains of the Iberian Chain; iii) the middle Muschelkalk facies (Mas Fm.) was assigned probably to the late Anisian-early Ladinian; iv) the upper Muschelkalk unit (Cañete Fm.) was dated as late Ladinianearly Carnian, and this unit was defined as diachronous, getting younger towards the NW, where it is Carnian in age; v) the lower part of the Keuper facies was dated as Carnian, and the upper part was considered to be probably Norian.

The palynological results of the present study partly agree with those of Doubinger et al. (1990), which derived from a much wider area located to the west. In the study area, all productive samples of the Röt facies and the lower and the middle Muschekalk units are attributed to the Anisian. This seems to agree with the Pelsonian assignment of the uppermost sandstone interval of the Buntsandstein facies (upper part of the Serra shales and Sandstones Fm. of Garay Martín, 2001) by Santos-Cubedo et al. (2014) near Bejís. The dating of this sandstone interval, which directly underlies the Röt facies, is based on tetrapod footprints. The lateral equivalent of the Serra Fm., i.e. the Eslida Formation of López-Gómez and Arche (1992), has been dated as Bithynian-Pelsonian by Juncal et al. (2018) in the Iberian Chain. In the study area all samples from the two carbonate-marl alternations in the upper Muschelkalk unit were assigned to the Ladinian.

In summary, the age of the Middle-Upper Triassic successions in the Alt Palància area is most likely slightly older than in the central and western areas of the Iberian Chain. This interpretation is based mainly on: i) the identification of only middle-late Anisian palynological assemblages in the middle Muschelkalk unit; and ii) the lack of assemblages clearly indicating a Longobardian or early Carnian age for the samples of the upper Muschelkalk unit. These results resemble those obtained by Solé de Porta et al. (1987) in the Triassic Catalan basin. In this basin, the sediments equivalent to the Röt facies were assigned to the early Anisian, and those of the middle Muschelkalk unit to the late Anisian (Stellapollenites thiergartii). The top beds of the upper Muschelkalk (Capafonts unit) was dated 
as Ladinian (possibly late Ladinian) and the Keuper facies as Carnian.

The comparison of the palynological data from the study area with available dating based on ammonoids remains difficult. No Anisian ammonoids have been identified in the Landete Fm. in the Iberian Chain (Goy, 1995; PérezValera et al., 2016) and Ladinian ammonoids have not been described previously in the stratigraphic sections of the Alt Palància. Only in the Bugarra section, located to the south of the study area, two Ladinian ammonoids have been identified in the Cañete Fm., one assigned to the early Fassanian and the other to the late Fassanianearly Longobardian (Escudero-Mozo et al., 2015). Other sections located in neighboring areas from which Ladinian ammonoids (Cañete Fm.) have been reported are Moyá, El Paraiso (Manzanera) and Agulles de Santa Àgueda (near the Castelló city) (Escudero-Mozo et al., 2015).

\section{Isotopic signatures}

The isotopic composition of the sulfate $\left(\delta^{34} \mathrm{~S}, \delta^{18} \mathrm{O}\right)$ and the isotope ratio of the strontium $\left({ }^{87} \mathrm{Sr} /{ }^{86} \mathrm{Sr}\right)$ are geochemical indicators of the origin of the sulfate minerals, mainly gypsum and anhydrite, in evaporites (Burke et al., 1982; Claypool et al., 1980; Korte et al., 2003; Wortmann and Paytan, 2012). In the case of the marine sulfates, these indicators have been used indirectly to estimate the ages of the ancient evaporite formations when these ages are not determinable by other methods.

Interpretation of isotopic data is done by comparison with data available from other Triassic basins of Iberia. Isotope data $\left(\delta^{34} \mathrm{~S}_{\mathrm{VCDT}}, \delta^{18} \mathrm{O}_{\mathrm{vSMOW}}\right)$ of calcium sulfates from these basins are found in Alonso-Azcárate et al. (2006), Iríbar and Ábalos (2011), Ortí et al. (2014), Ortí et al. (2018) and Utrilla et al. (1992), amongst others. Data from the Betic, Iberian and Catalan basins are as follows (Table 2): The Keuper facies is characterized by values that mainly range between 13.8 and $15.6 \%$ for $\delta^{34} \mathrm{~S}$, and between 10.0 and $16.9 \%$ for $\delta^{18} \mathrm{O}$. The middle Muschelkalk facies is characterized by $\delta^{34} \mathrm{~S}$ values between 16.4 and $18.7 \%$, and by $\delta^{18} \mathrm{O}$ values between 10.3 and $16.5 \%$. Accordingly, the Keuper facies has lighter $\delta^{34} S$ values than those of the middle Muschelkalk facies, although the $\delta^{18} \mathrm{O}$ values are similar in the two facies.

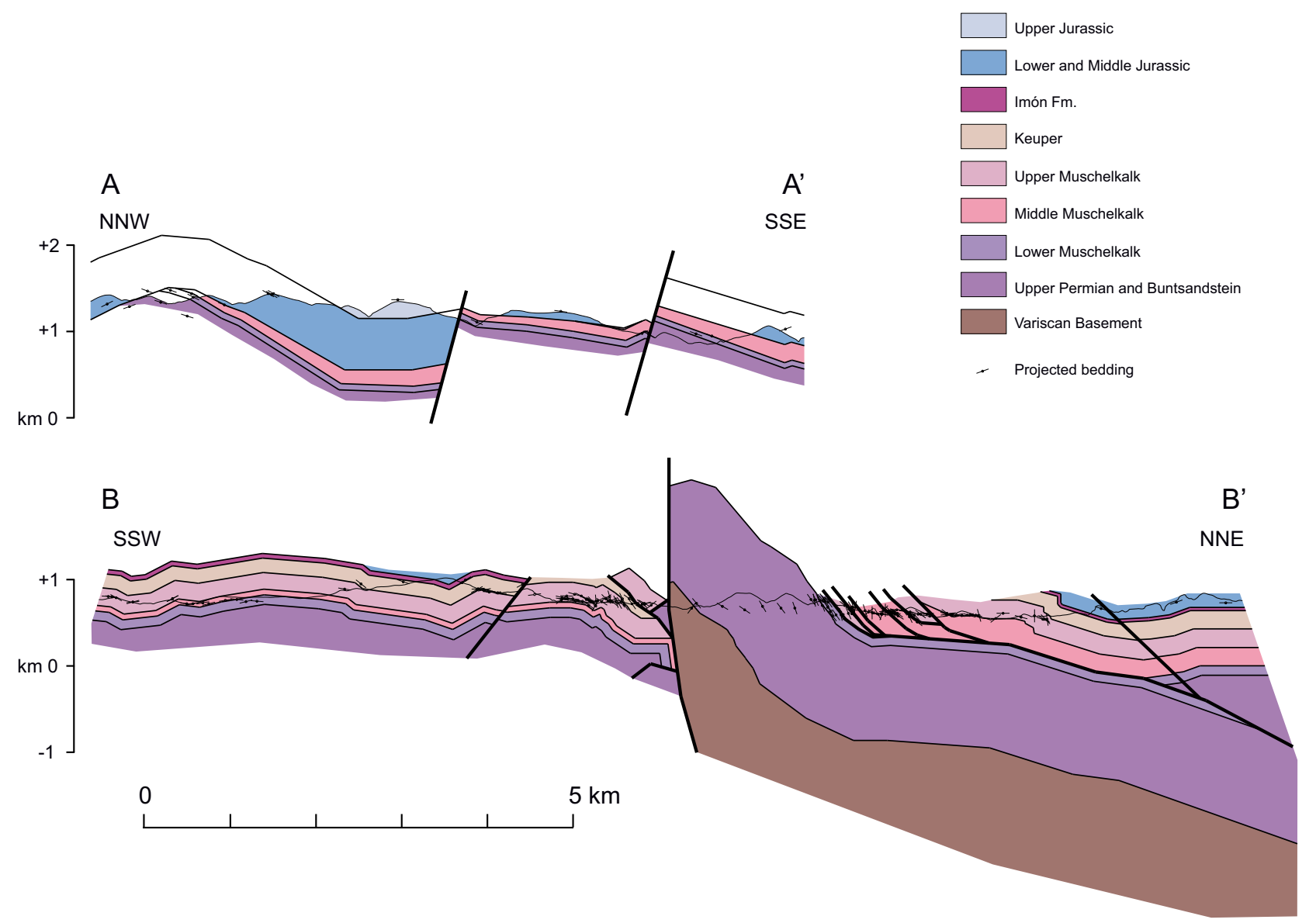

FIGURE 5. Geological cross sections in A) the Andilla-Bejís and the Almarja Triassic outcrops and B) in the Montán and Caudiel Triassic outcrops. 
The gypsiferous units that, according to the cartographicstratigraphic criteria, belong to Keuper units have $\delta^{34} \mathrm{~S}$ values (10 samples) between 14.0 and $15.5 \%$ and a mean of $14.4 \%$ ( $\delta^{18} \mathrm{O}$ values ranging between 11.5 and $16.4 \%$ ) (Table 2; Fig. 9A). However, the $\delta^{34} \mathrm{~S}$ values between 14.0 and $14.5 \%$ are predominant. The gypsiferous units that, according to the cartographic-stratigraphic criteria, belong to the middle Muschelkalk unit (14 samples) have $\delta^{34} \mathrm{~S}$ values ranging between 15.6 and $17.8 \%$, and a mean of
$16.4 \%$ ( $\delta^{18} \mathrm{O}$ values ranging between 12.8 and $18.0 \%$ ). In the case of gypsiferous units whose stratigraphic position was uncertain due to tectonism, they were assigned based on the values listed above to the Keuper and the middle Muschelkalk units.

In addition, the following specific observations are highlighted (Fig. 9A): i) the samples belonging to the K5 unit (top of the Keuper facies) can be distinguished

\section{SW - NE}

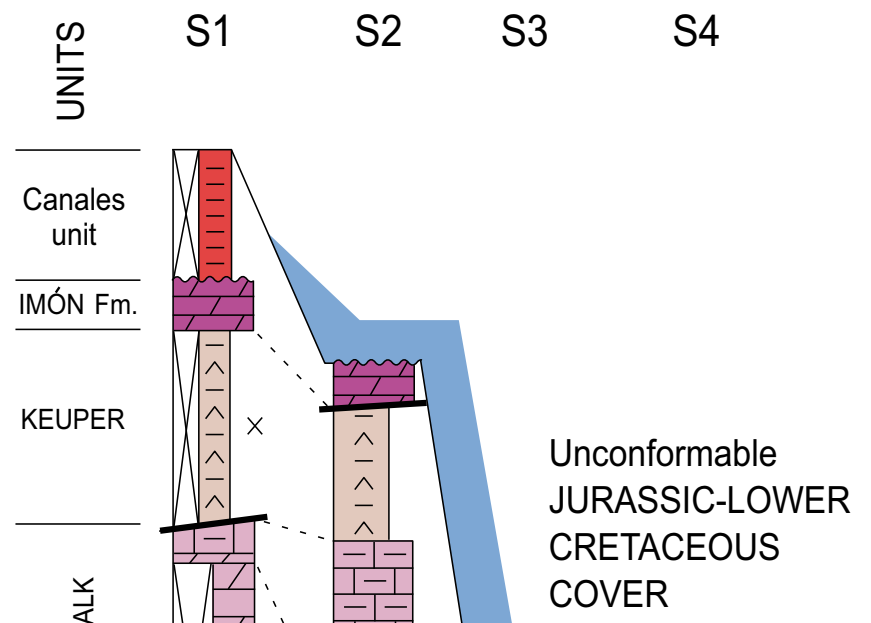

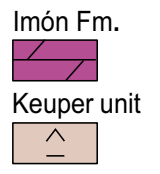

MUSCHELKALK UNITS

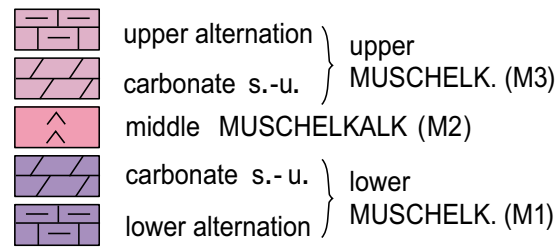

Palynological assemblages

- Ladinian (early?)

$\left.\begin{array}{ll}\bigcirc & \text { undivided } \\ & \text { late } \\ \text { early / middle }\end{array}\right\}$ Anisian

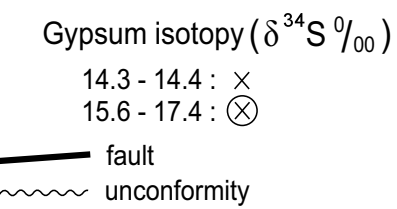

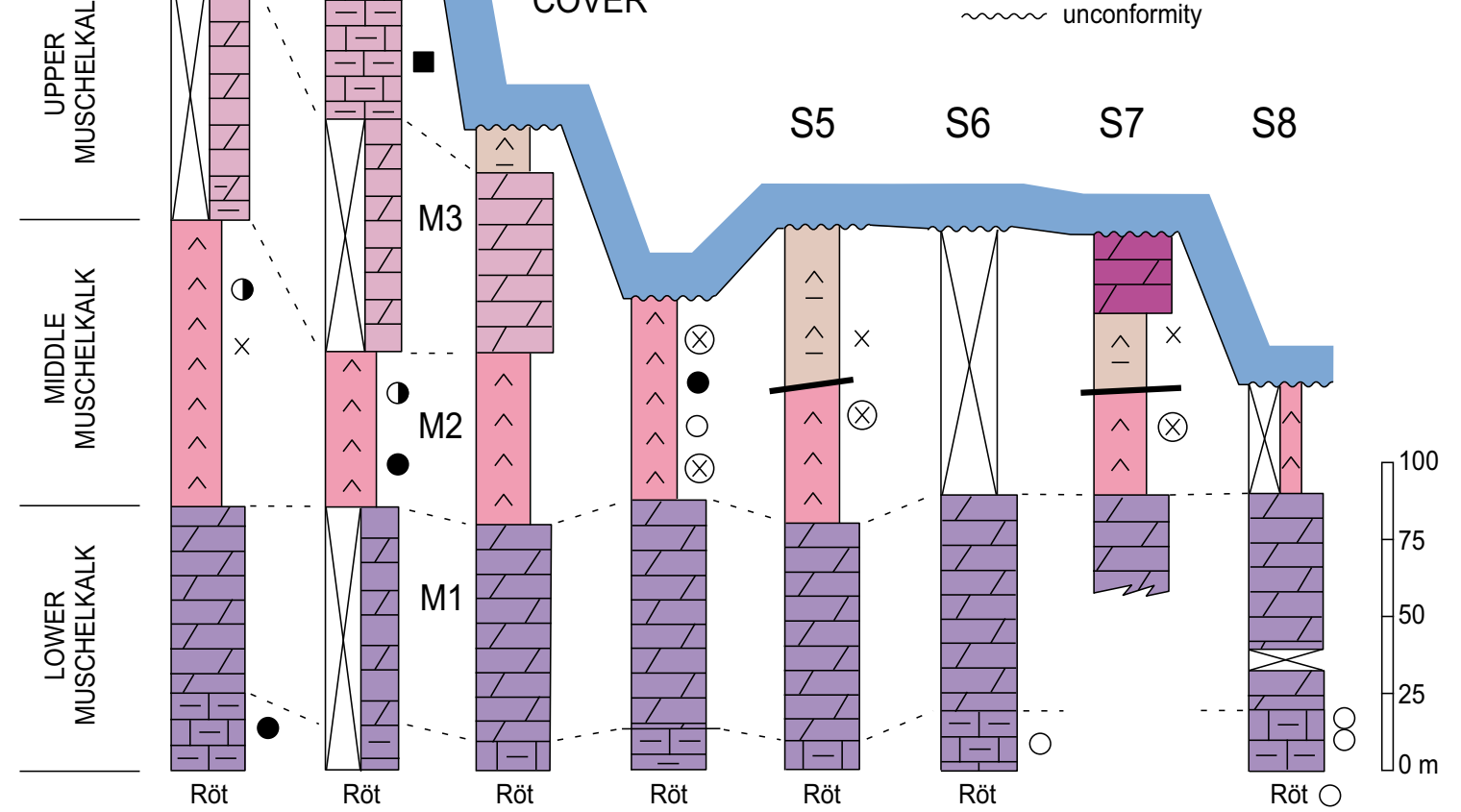

FIGURE 6. Simplified stratigraphic sections of the Middle-Upper Triassic in the Andilla-Bejís and Almarja outcrops. Sections: S1 Andilla; S2 Canales; S3 Resinero creek; S4 Almarja; S5 Arteas village; S6 Arteas creek; S7 Bejís (Palància river); and S8 Molinar. U.T.M. coordinates (ED50; zone 30 in all the sections) of the base of the sections: S1: X: 688982, Y: 4413281; S2: X: 690631, Y: 4416787; S3: X: 688918, Y: 4418190;S4: X: 688968, Y: 4424060; S5: X: 0693488, Y: 4420200; S6: X: 694889, Y: 4420113; S7: X: 695804, Y: 4420903; S8: X: 693585, Y: 4423892. 
isotopically from those belonging to older Keuper units (K1 and K4); ii) for both the Keuper and the middle Muschelkalk units, the $\delta^{18} \mathrm{O}$ values are more variable than those of $\delta^{34} S$ and iii) in the six pairs of samples assigned to the Keuper units, the values between the two samples in each pair ranges from 0.0 to $0.9 \%$, and in the four pairs assigned to the middle Muschelkalk unit it ranges from 0.2 to $0.8 \%$; iv) in contrast, the two pairs of samples taken in one of the gypsiferous units of the Andilla-Bejís outcrop show different values (Fig. 9A). These pairs are 120-119 near Arteas in section S5 and 101-126 near Bejís in section S7 (Fig. 3). This mapped unit was expected to be middle Muschelkalk according to its stratigraphic position. However, the two pairs show $\delta^{34} \mathrm{~S}$ values that correspond one to the middle Muschelkalk and the other to the Keuper (16.3 and $14.4 \%$ respectively in S5; 15.8 and $14.3 \%$ respectively in $\mathrm{S} 7$, with value differences of $1.9 \%$ and $1.5 \%$, respectively; Table 2). A juxtaposition due to faulting of the gypsiferous masses belonging to these two facies is assumed.

Regarding the twenty-two samples studied for comparison with other Triassic outcrops, the $\delta^{34} \mathrm{~S}$ values assigned to the Keuper facies range from 13.3 to $15.6 \%$ o and those assigned to the middle Muschelkalk unit range from 15.7 to $16.7 \%$ (Fig. 9B, Table 2).

Despite local variations, the former stratigraphic assignments of the gypsum samples in the Alt Palància region and in the surrounding Triassic outcrops agree with the available isotope values $\left(\delta^{34} \mathrm{~S}, \delta^{18} \mathrm{O}\right)$ in other Iberian basins (see above). Therefore, in the study area of the eastern Iberian Chain it can be assumed that the middle Muschelkalk and the Keuper units can be differentiated based on the gypsum-anhydrite isotope chemistry. However, the boundary for the $\delta^{34} \mathrm{~S}$ values is not as sharply differentiated as in the Triassic Catalan basin (Fig. 9B). This fact could be attributed to specific hydrochemical conditions in each basin such as different Bacterial Sulfate Reduction (BSR), or different supply of nonmarine water (variations of the isotope values have been documented also in the various sub-basins of the Triassic Germanic basin; Bernasconi et al., 2017). Consequently, the attribution either to the Keuper or to the middle Muschelkalk of the $\delta^{34} \mathrm{~S}$ values in the interval 15.5-15.7\% requires consideration of other associated values in the same unit, and geological (cartographic, stratigraphic) criteria. In this study, samples with $\delta^{34} \mathrm{~S}$ value of $15.5 \%$ or lower were assigned to the Keuper facies and those of $15.7 \%$ or higher to the middle Muschelkalk facies. Two values of $15.6 \%$ were recorded. One was assigned to a middle Muschelkalk unit (sample 117; Alt Palància area in Table 2) and the other to a Keuper unit (sample 153; other areas in Table 2).

\section{DISCUSSION}

\section{Structural control on the sedimentation}

Grabens containing up to $700 \mathrm{~m}$ of Upper PermianTriassic Buntsandstein facies have been recognized bounded by normal faults separating them from thinner successions (Arche and López Gómez, 1996; Guimerà et al., 2004). Gómez-Gras (1993), Martín-Martín et al. (2005; fig. 3.18) and Martín-Martín et al. (2006) have recorded a thickness of this facies of about $900 \mathrm{~m}$ in the Espina and Espadà ridges. Hence, the $1080 \mathrm{~m}$ succession found to the north of the Espina-Espadà Fault is the thickest Upper Permian and Buntsandstein succession found in the entire Iberian Chain.

The thickness variation observed in the Middle-Upper Triassic stratigraphic units in the Alt Palància area are shown in Figure 10. Only small thickness variation (between 20 to $25 \mathrm{~m}$ ) was observed in the Röt facies (uppermost Buntsandstein). The thickness of the lower Muschelkalk unit (between 80 and 104m) is of paleogeographic relevance given that this unit has remained uneroded in all the outcrops. The thickness of the sub-units forming the lower Muschelkalk unit in the studied sections is shown in Figure 11.

The original thickness of the middle Muschelkalk unit is difficult to estimate due to tectonic migration. In the present study, minimum values of $80 \mathrm{~m}$ were estimated in the Andilla-Bejís area, and >100m in the Montán outcrop. In the latter outcrop, however, the depositional thickness could have been higher, of about 100-200m (Fig. 5, B-B').

The original thickness of the upper Muschelkalk unit is also difficult to estimate. This is because i) the unit is found variably eroded in the Andilla-Bejís, Almarja and Torás outcrops (Fig. 6), and ii) the unit is found interstratified between the very plastic middle Muschelkalk and Keuper units and has lost its lower and/or its upper carbonatemarl alternations in many places due to tectonism. Large thicknesses variation range between 0 and almost $200 \mathrm{~m}$ (Fig. 10) in the different outcrops. The thickness of the subunits forming the upper Muschelkalk unit in the studied sections is shown in Figure 11.

The estimated thickness of the Keuper facies in the study area varies between 50 and $100 \mathrm{~m}$. The thickness of the Imón Fm. shows marked differences in the various outcrops ( 15 to $>40 \mathrm{~m}$ ) suggesting partial erosion below the Jurassic cover in places. Maximum thickness of the Imón Fm. is found near the Pina de Motalgrao village (section S16). The Canales red claystone unit shows a thickness of about 40m in the Andilla-Bejís outcrop (S1 and S2 sections). 


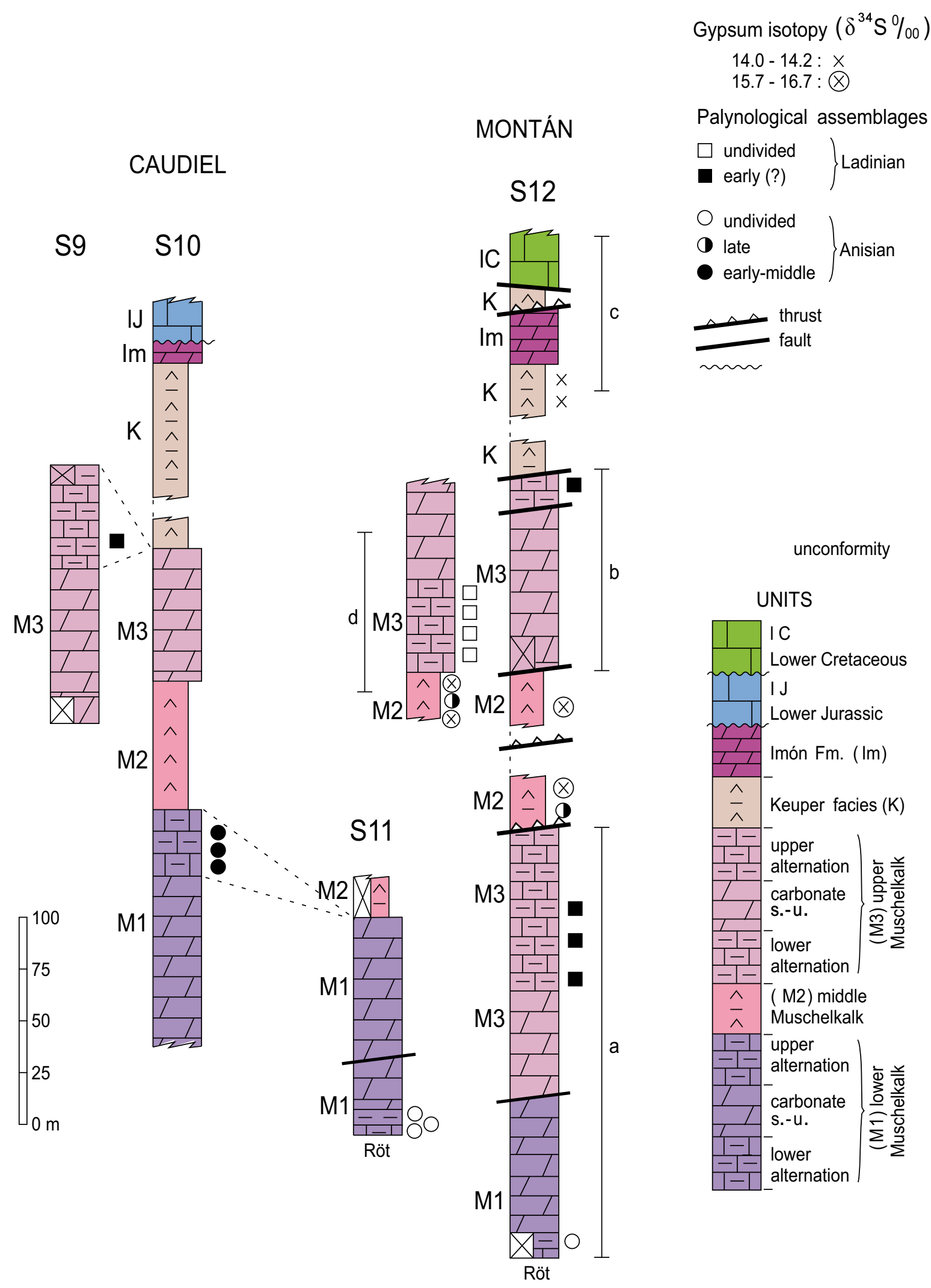

FIGURE 7. Simplified stratigraphic sections of the Middle-Upper Triassic in the Caudiel and Montán outcrops. Sections: S9 Masadas Blancas (old mining railway); S10 Caudiel composite section; S11 Cueva Cirat; S12 Montán composite section (a, b, c, d).U.T.M. coordinates (ED50; zone 30) of the base of the sections: S9: X: 703466, Y: 4426961; S10: X:705115, Y: 4428185; S11: X: 707676, Y: 4433841; S12(a): X: 708404, Y: 4433745; S12(b): X: 709378, Y: 4435957; S12(c): X: 709377, Y: 4436487; S12(d):X: 708245, Y:4434773. 
Considering the entire Middle-Upper Triassic succession (Figs. 5; 7; 8), its estimated original thickness suggests that two different parts can be distinguished in a SW-NE transect across the Alt Palància. A southern part includes the Almarja, Andilla-Bejís, Torás, and Caudiel outcrops, and the Montán outcrop represents a northern part. The maximum accumulated thickness of the two carbonate Muschelkalk units is estimated to be about $205 \mathrm{~m}$ in the Andilla-Bejís outcrop (S1 and S2 sections), and $290 \mathrm{~m}$ in the Montán outcrop where both the lower and the upper alternations of the upper Muschelkalk unit are well developed locally (sections S12 to S16). The middle Muschelkalk unit in the Montán outcrop also seems to be thicker than that in the Andilla-Bejís outcrop.
Because of the structural complexity of the succession in this zone, previous studies contain very different interpretations of the Middle-Upper Triassic successions in Montán (Castillo, 1980; Garay Martín, 2001, 2005a; Jerez Mir, 1996; LópezGómez et al., 1998). However, all previous assignments of the carbonate Muschelkalk facies either to the lower or the upper Muschekalk units, and of the evaporitic deposits either to the middle Muschelkalk or to the Keuper facies, were not supported by paleontological and geochemical evidence.

A summary of the stratigraphic results of the present study is shown in Figure 10. The NW-SE-oriented EspinaEspadà Fault separates a thinner succession of the AndillaBejís-Caudiel sector in the SW from a thicker succession in the Montán sector in the NE. Also, lateral facies changes

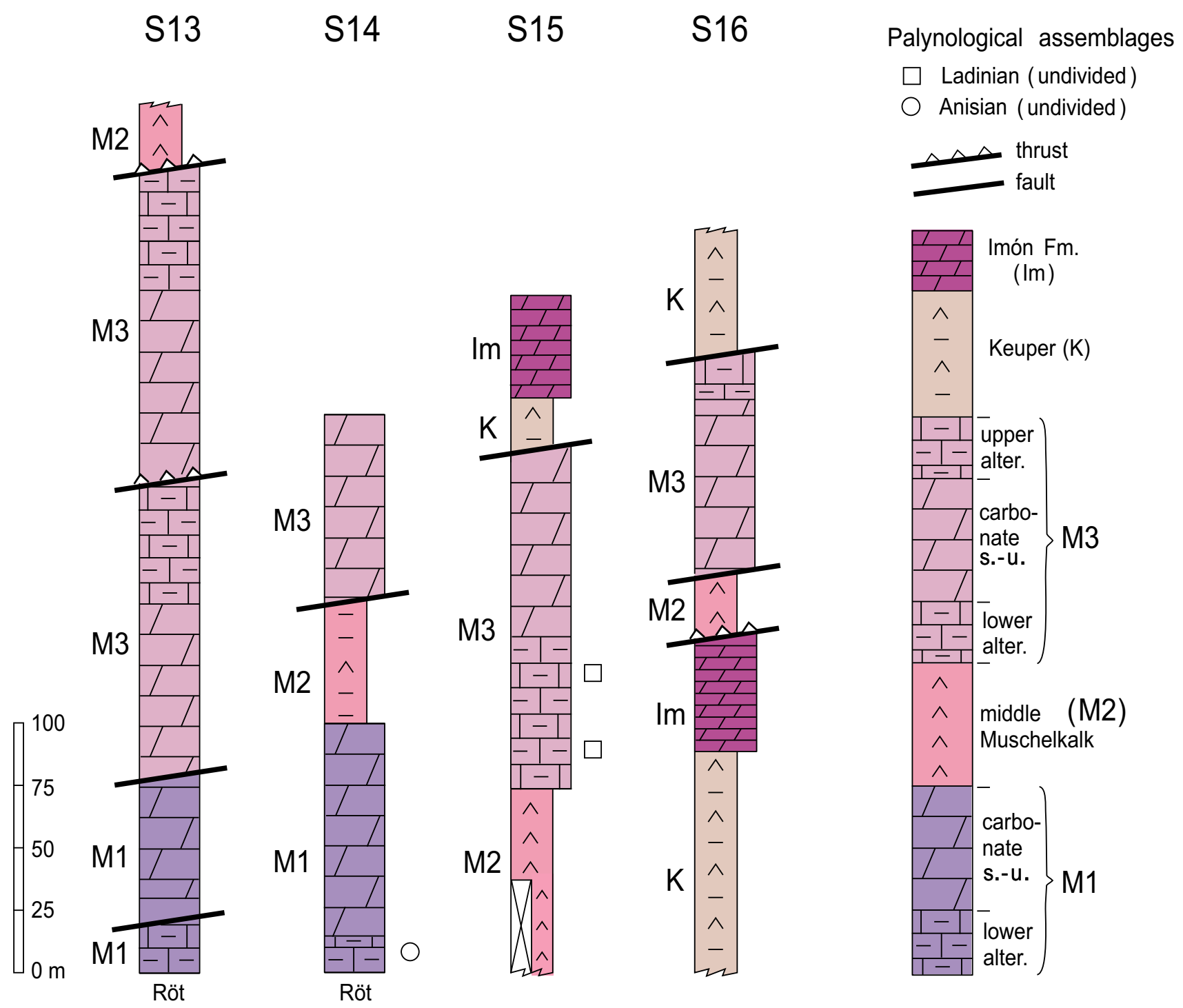

FIGURE 8. Simplified stratigraphic sections of the Middle-Upper Triassic exposed in the Montán outcrop. Sections: S13 (Fuente del Plano creek); S14 (Fuente la Reina track); S15 Pina de Montalgrao-south; S16 Pina de Montalgrao-north. U.T.M. coordinates (ED50, zone 30) of the base of the sections: S13: X: 709505, Y: 4433353; S14: X: 704657, Y: 4435505; S15: X: 700117, Y: 4432908; S16: X: 700074, Y: 4433392. 
exist in the carbonates of the Muschelkalk units at both sides of this fault.

The upper carbonate-marl alternation of the lower Muschelkalk unit, present in the Caudiel outcrop was not found in the other outcrops of the study area. Two possible interpretations of this are: i) it was sedimented only in the Caudiel outcrop overlying the carbonate sub-unit and ii) it represents a lateral facies change into the upper part of the carbonate sub-unit. In the latter interpretation, the upper alternation is a lateral equivalent of the El Sierro Mb. (top member of the Oronet Fm.) of Garay Martín (2001).
In summary, both NW-SE and NE-SW-striking normal faults were active during the deposition of Triassic rocks in the Alt Palància area. Striking differences in depositional thickness and facies were also recorded by Gómez (1979) in the Jurassic successions of the northern part of the Alt Palància due to NW-SE-oriented faults ('Fault Zone of Caudiel'). Moreover, igneous rocks appear in this area assigned to the Late Triassic (ophitic dolerites) and the Early-to-Middle Jurassic (basalts and trachybasalt flows and pyroclastic deposits; see Ortí and Vaquer, 1980), as documented in several studies near Caudiel (Cortés and Gómez, 2016; Cortés, 2018; Gómez and Goy, 1977). The
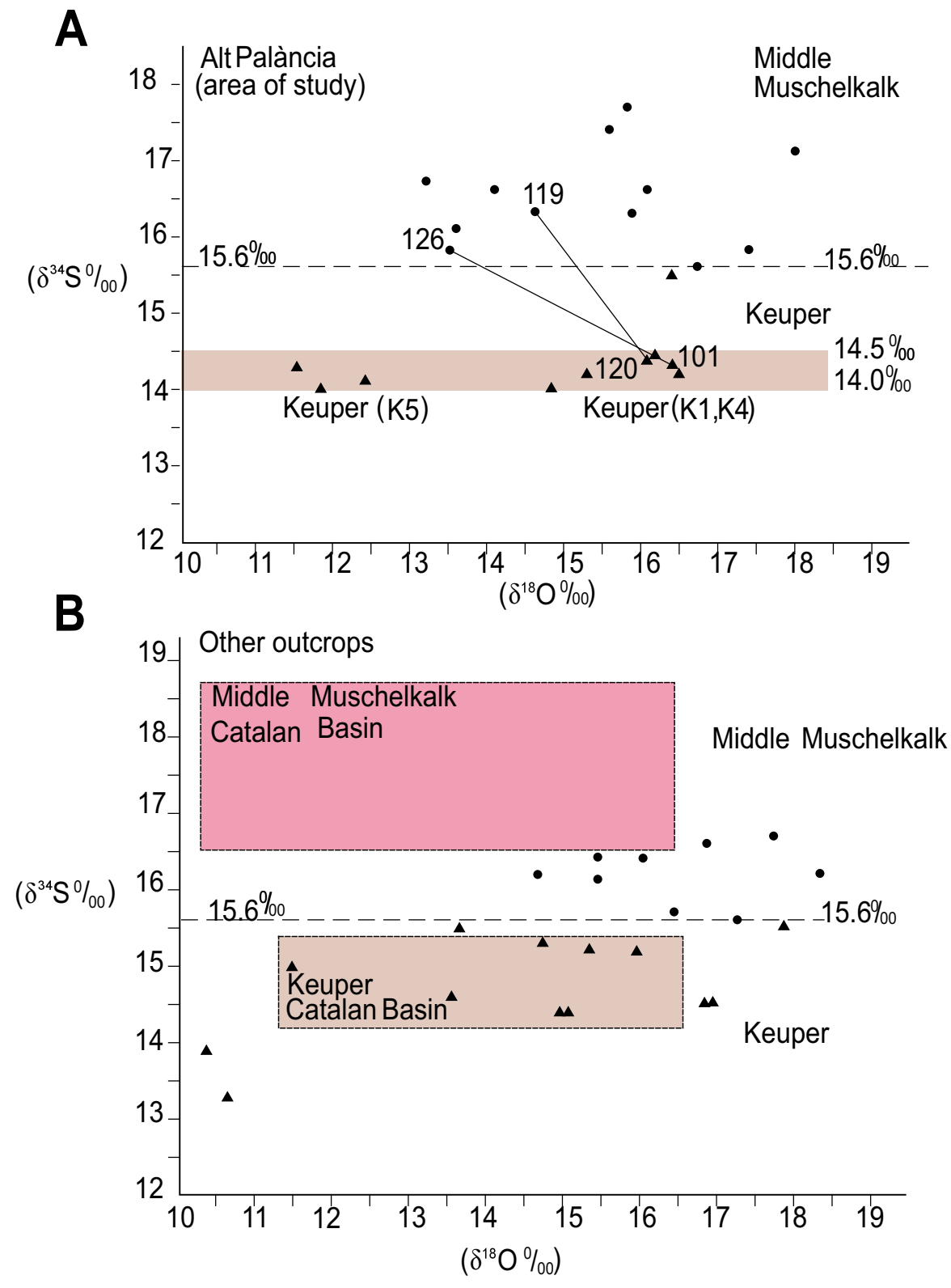

FIGURE 9. Isotopic values of Middle-Upper Triassic gypsum samples. A) Study area in the Alt Palància. The two lines join pairs of values in the same mapping unit of the Bejís-Arteas outcrop (samples 119 and 120 in section S5; samples 126 and 101 in section S7). B) Other outcrops studied. The projection areas of the sulfate isotope values in the Catalan basin (after Ortí et al., 2018) are represented. In the two figures the $\delta^{34}$ S values of $15.6 \%$ are used as boundary. Dots: middle Muschelkalk samples. Triangles: Keuper samples. 
Espina-Espadà Fault can be related to the 'Molina-TeruelEspadà' fault of López-Gómez and Arche (1994) and of Arche and López-Gómez (1996). Regarding the NESW-striking faults, which are predominant in the Triassic blocks of the Andilla-Bejís outcrop, they may be related to the 'Castelló fault system' recognized in the Desert de les Palmes and surrounding areas by Roca and Guimerà (1992) and by López-Gómez et al. (2005). According to LópezGómez et al. (2005), the influence of this system, which is formed by subordinate, normal faults parallel to those of the Requena and Teruel major faults, is recorded at least since middle Anisian times.

\section{The Triassic-Jurassic boundary}

Non-parallel contacts at the Triassic-Jurassic boundary are common in the eastern Iberian Chain. Such contacts have been traditionally attributed to tectonic detachments between the Keuper facies and the overlying carbonates caused by the Alpine tectonism. This interpretation is predominant in the geological maps at 1:50,000 scale (MAGNA program) and in the maps at 1:200,000 scale published later by IGME (IGME, 1985a, b). See Garay Martín (2001) for a review of this subject.

In the studied outcrops of the Alt Palància, however, Jurassic carbonates of different ages (Early, Middle, and Late Jurassic) and Lower Cretaceous siliciclastics are in contact with the underlying Triassic sediments by fault or by angular/erosive unconformities. The unconformable contacts are present particularly in the Andilla-Bejís (Canales-Bejís area and Resinero block), Torás, and Almarja outcrops. In the Caudiel and Montán outcrops, only the carbonates of the Cortes de Tajuña Fm. (lowermost Jurassic) rest unconformably on a partly eroded Imón Fm.

This angular/erosive unconformity at the TriassicJurassic boundary has been documented in other areas of the Iberian Chain. It is related to the semigraben shaped accumulation of the Triassic sediments at the TriassicJurassic boundary, the overlying carbonates being dated as Hettangian to Pliensbachian (Aurell et al., 1992; Gallego et al., 1994; Guimerà et al., 2004; Nebot, 2016; Nebot and Guimerà, 2016a, b; Roca and Guimerà, 1992; San Román and Aurell, 1992).

In the outcrops of the Alt Palància area it appears that the bounding faults of the tilted blocks (Andilla-Bejís and other outcrops) were reactivated during the different extensional pulses in the Jurassic and Cretaceous, in particular in the latest Jurassic-Early Cretaceous rifting phase of Salas and Casas (1993). The reactivation led to the tilting of blocks between faults and the formation of new angular unconformities. Late Triassic to Early Cretaceous unconformities have been documented in many other outcrops of the eastern Iberian Chain, e.g. in the Llucena outcrop (Guimerà, 1987). One of these Jurassic angular unconformities, the one which occurred at the boundary between the Lower and the Middle Jurassic, has been recently documented by Santisteban Bové (2016, 2018) in the southwestern corner of the Jérica map (La Salada massif) and the neighboring Alcublas area (IGME, 1975). According to this author, this extensional phase caused faulting in the carbonate sequence into small tilted blocks and the ejection of pyroclastic materials.

\section{Type of Triassic successions in the Alt Palància area}

The Middle-Upper Triassic in the Alt Palància belongs to the Mediterranean Triassic as it was proposed earlier for the València area by Virgili et al. (1977) and Sopeña et al. (1983) and was later assumed for the whole area of the present study by López-Gómez et al. (1998).

López-Gómez et al. (1998) assigned the successions in the easternmost part of the Iberian Chain to the 'LevantineBalearic' type of Triassic, in which the Muschelkalk facies had a single, comprehensive carbonate unit of late Anisian-Ladinian age. Apart of the Minorca Island, this Triassic domain extended from the coast of CastellóValència towards the west in a narrow band that involved only the eastern parts of the Espadà-Calderona area. The Triassic sections of Xòvar, Serra and Gàtova-Marines were included in this band, although the Montán section of the Alt Palància and other sections located further to the west were excluded from it.

The landward area of this 'Levantine-Balearic Triassic' has been considerably enlarged towards the west, the north, and the south by Escudero-Mozo (2015) and EscuderoMozo et al. (2015; fig. 1) based on new paleontological studies in the Muschelkalk facies. In such a modified area, these authors have distinguished i) a northern part including the Maestrat, the Calderona-Espadà, most of the Alt Palància (stratigraphic sections of Molinar and Cueva Cirat), and other areas to the NE and ii) a $\mathrm{z}<$ asouthern part located to the southwest of the Calderona Ridge. In the two parts of this enlarged Triassic, Escudero-Mozo et al. (2015) have identified only a single carbonate unit (100-140m thick) as upper Muschelkalk facies, i.e. the Cañete Fm., of late Illyrian-Longobardian age (uppermost Anisian-late Ladinian). Also, according to these authors, this formation rests directly on the Buntsandstein facies in the northern part of this Triassic (enlarged paleogeographic high), whereas it rests on undetermined rocks in the southern part.

Regarding the northern part of the enlarged 'LevantineBalearic Triassic', the new definition by Escudero-Mozo et al. (2015) implies the non-deposition of the first marine transgressive cycle of the Triassic, which, according to these 
authors, is formed by the Röt facies, the Landete Fm., and the lower part of the Mas Fm. Based on this interpretation, a thin Landete Fm. (30-49m thick) would have been deposited during the late Pelsonian-early Illyrian (Anisian) in a very narrow landward area of the Mediterranean Triassic located to the west.

Differences, however, exist between this specific stratigraphic interpretation (the enlarged paleogeographic high) in Escudero-Mozo et al. (2015) and those in other published and unpublished sources. These sources refer to both, the subsurface data in the Maestrat area and the surface observations provided in numerous publications and reports on the CalderonaEspadà area, and other areas to the north. Several studies dealing with the subsurface Mesozoic stratigraphy in the Maestrat area (Bartrina and Hernández, 1990; Lanaja, 1987; Martínez-Abad, 1991; Nebot, 2016; Nebot and Guimerà, 2016a, b) have documented the presence of the three Muschelkalk units originally described in Catalonia. In the deep boreholes of this sector, Bartrina and Hernández (1990) assigned thicknesses up to $>200 \mathrm{~m}$ to the carbonatic lower Muschelkalk unit, $>600 \mathrm{~m}$ to the evaporitic middle Muschelkalk unit (chlorides and sulfates), and $130 \mathrm{~m}$ to the carbonatic upper Muschelkalk unit (deep boreholes of Mirambell-1, Maestrazgo-2, and Bobalar-1). This Middle Triassic succession rests on a $50-200 \mathrm{~m}$ thick unit of Buntsandstein facies. Moreover, and based on the study of seismic profiles, Nebot (2016) and Nebot and Guimerà (2016a, b) have documented the internal structure of this thick, evaporitic middle Muschelkalk unit. The assignment of this evaporitic unit to the middle Muschelkalk facies has been recently corroborated in Ortí et al. (2018) based on the isotopical composition of anhydrite samples in two of the deep boreholes of the Maestrat area. Offshore and south of the Ebro delta (Fig. 2), several oil wells record Triassic successions including lower, middle and upper Muschelkalk units with total thicknesses ranging from about 150 to $360 \mathrm{~m}$

STUDIED OUTCROPS

$\begin{array}{ccc}\begin{array}{c}\text { Andilla-Bejís and Almarja } \\ (\mathrm{S} 1 \text { to } \mathrm{S} 8)\end{array} & \begin{array}{c}\text { Caudiel } \\ (\mathrm{S} 9, \mathrm{~S} 10)\end{array} & \text { Montán } \\ \text { (S11 to } \mathrm{S} 16)\end{array}$

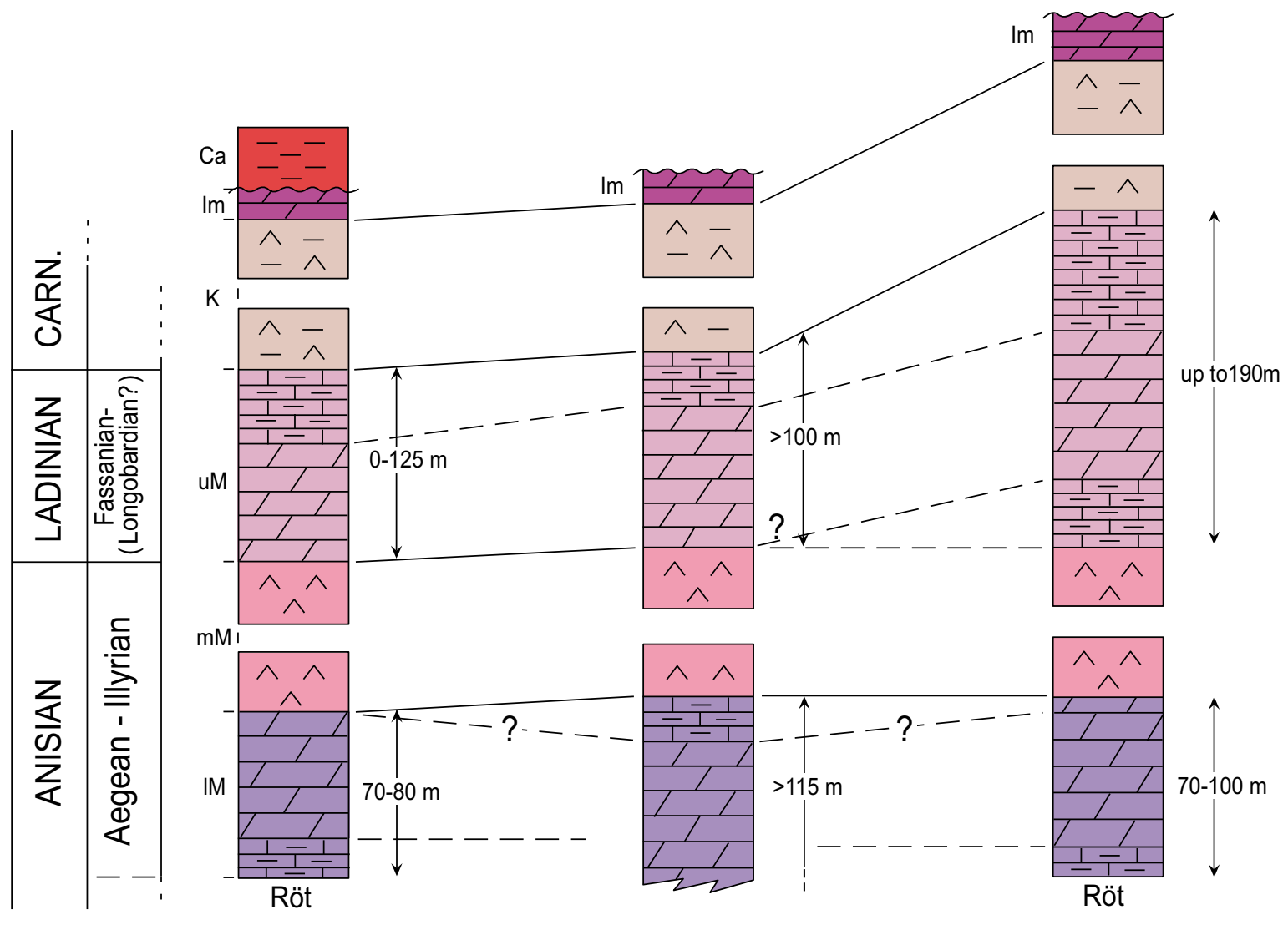

FIGURE 10. Compilation of representative sections of the Middle-Upper Triassic successions exposed in the main outcrops of the study area. 
(Klimowitz et al., 2018, Fig. 3). Only two boreholes (Salzadella-1, Maestrazgo-1) in the easternmost Maestrat area have recorded absence of Muschelkalk deposits due to synsedimentary fault activity of a NESW-trending, NW-dipping normal fault. The existence of this paleohigh could have caused the absence of lower and middle Muschelkalk record in the Desert de les Palmes near the Castelló city, where a 90m thick carbonatic succession, initially identified by LópezGómez et al., 1998), has been reassigned to the upper Muschelkalk unit by Escudero-Mozo et al. (2015).

Several surface and mapping studies carried out in many of the extensive Triassic outcrops of the northern part of the 'Levantine-Balearic Triassic' of EscuderoMozo et al. (2015) have documented the presence of the three Muschelkalk units known in the Mediterranean Triassic (Calderona-Espadà, Alt Palància, Alt Millars, and Llucena-Villahermosa del Río outcrops). The mapping works include several Geological maps at scale 1:50,000 of the MAGNA program and several Geological maps at scale 1:200,000, all edited by IGME during the seventies and eighties of the last century, as well as (unpublished) extensive geological mapping by Garay Martín (2001). The studies are those of Castillo (1980), Garay Martín (2001; 2005a, b), Guimerà (1987), Jerez Mir (1996), and Ortí and Guimerà (2015), amongst others. The isotope data of gypsum samples obtained in this study for the Fanzara and Villahermosa del Río outcrops (Table 2) also substantiate the existence of a middle Muschelkalk unit to the south of the Maestrat area.

\section{CONCLUSIONS}

The multidisciplinary study of the Middle-Upper Triassic rocks cropping out in the Alt Palància area allows establishing the following conclusions.

Normal faults striking WNW-ESE in the Montán outcrop (Espina-Espadà Fault) and NE-SW in the AndillaBejís and Almarja outcrops were active during the deposition of Triassic rocks. The NNE hanging-wall of the Espina-Espadà Fault contains more than 1000m of Upper Permian and Lower Triassic (Buntsandstein facies) redbeds. This is the maximum thickness of these units found in the entire Iberian Chain. The Espina-Espadà Fault was inverted during the Cenozoic as a reverse fault. Folds and thrusts developed in its foot-wall, whereas an imbricate thrust-system detached mainly at the middle Muschelkalk facies developed in its hanging-wall.

A SE tilting and partial erosion of the Triassic rocks before the deposition of Jurassic rocks is evidenced by an angular unconformity in the Andilla-Bejís, Almarja, and Torás outcrops. Some faults affecting the Triassic also involve Jurassic rocks and tilt them.

Three sub-units form the lower Muschelkalk: carbonate sub-unit, and lower and upper carbonate-marl alternations. The lower alternation is present in all the outcrops, whereas the upper alternation is only found in the Caudiel outcrop.

Three sub-units also form the upper Muschelkalk: carbonate sub-unit, and lower and upper carbonate-marl

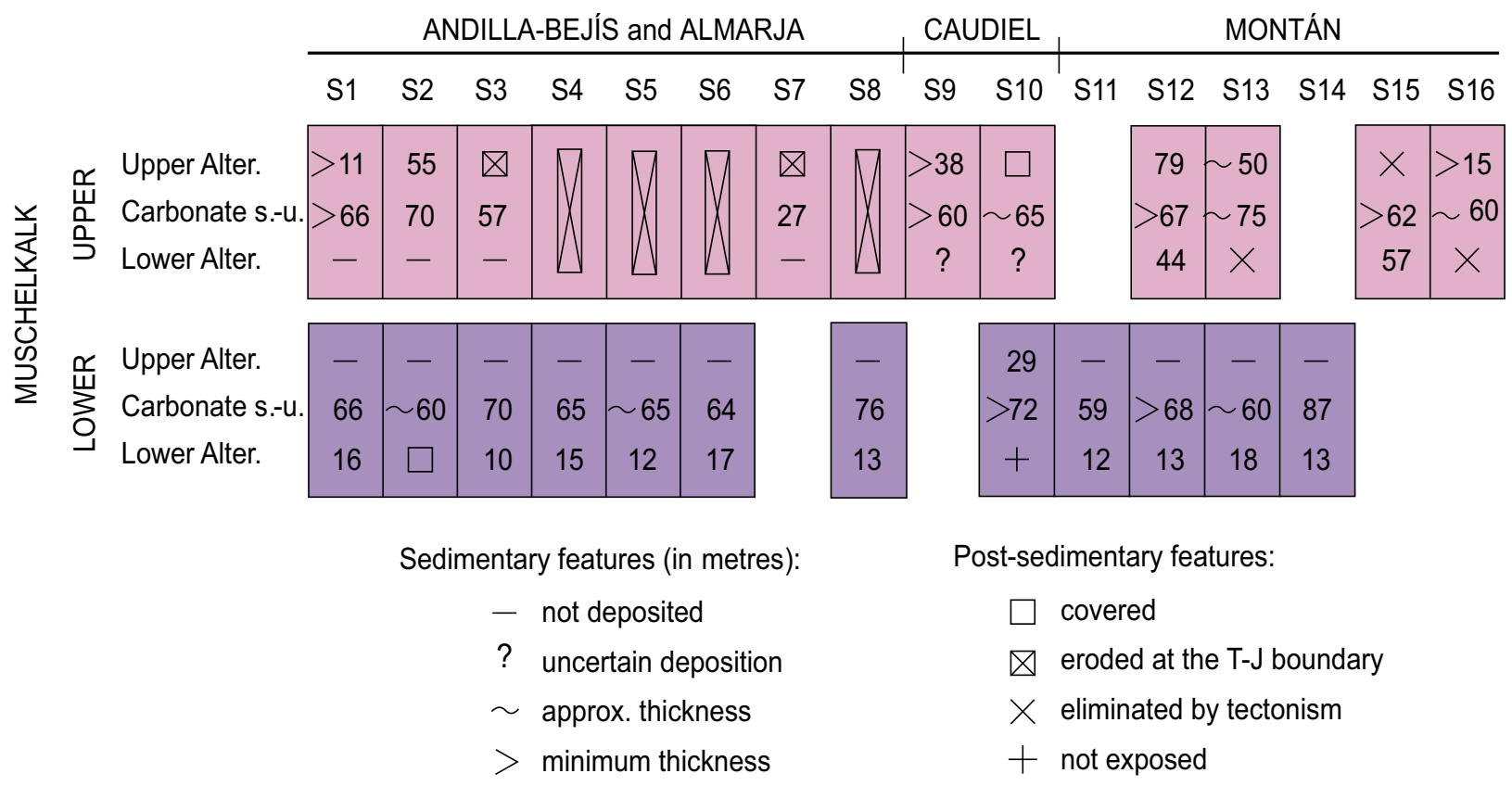

FIGURE 11. Thickness of the sub-units forming the lower and the upper Muschelkalk units in the studied sections grouped by outcrops. 
alternations. However, the presence of the lower alternation is uncertain to the SW of the Espina-Espadà Fault, while the upper alternation was deposited in both sides of the fault.

A probably thick grey marly-gypsiferous unit forms the base of the middle Muschelkalk facies. However, a complete stratigraphic succession was not clearly identified. In the Keuper facies, also a lower grey unit forms the base (K1 unit), which is overlain by an upper red unit (K4) and a top laminated gypsum unit (K5 unit).

The thickest succession of Middle-Upper Triassic is exposed in the Montán outcrop suggesting a synsedimentary control of the Espina-Espadà Fault (about $290 \mathrm{~m}$ accumulated for the two Muschelkalk carbonate units, and, probably more than $300 \mathrm{~m}$ for the assemblage of the Keuper and the middle Muschelkalk facies). However, the precise thicknesses of the successions are difficult to calculate because of i) the high plasticity of the clayeygypsiferous materials of the middle Muschelkalk and the Keuper facies and ii) the plasticity of the carbonate-marl alternations, which are often pinching out or have been eliminated tectonically.

The succession of Middle-Upper Triassic was found partly eroded in many places of the study area (Almarja and Torás outcrops, and in a large part of the Andilla-Bejís outcrop). In these places, angular unconformities occur between the Triassic rocks and the overlying Mesozoic rocks (Jurassic carbonates of different ages or siliciclastics of the Lower Cretaceous). In the other outcrops, only an unconformity between the Imón Fm. and the Lower Jurassic carbonates is observed.

Palynological data from the Alt Palància allow dating the Röt facies and the lower and middle Muschelkalk units as Anisian. The upper Muschelkalk unit is Ladinian in age, although the presence of the Longobardian stage based on palynomorphs remains unproved.

The sulfates of the middle Muschelkalk and the Keuper units can be distinguished by their respective isotopic compositions $\left(\delta^{34} \mathrm{~S}\right.$ and $\left.\delta^{18} \mathrm{O}\right)$. In the Alt Palància, the $\delta^{34} \mathrm{~S}$ values range from 14.0 to $15.5 \%$ in the Keuper unit, and from 15.6 to $17.8 \%$ in the middle Muschelkalk unit. Similar values were obtained in other outcrops surrounding this area. These determinations were crucial for the mapping and the stratigraphic studies, because no discrimination of these two evaporitic units based on facies was possible. The isotopic determinations also help to identify specific outcrops where a tectonic juxtaposition occurs between the clayey-marly-gypsiferous materials of the middle Muschelkalk and the Keuper units.
The Mediterranean type of the Triassic (sensu LópezGómez et al., 1998; Virgili et al., 1977) extends throughout the entire Alt Palància region. It is proposed that this integrated multidisciplinary approach can be applied to other Triassic basins in Iberia or to other geological domains where the carbonate-evaporite successions have been tectonically disrupted.

\section{ACKNOWLEDGMENTS}

This study was supported by research projects CGL201566835-P and CGL2016-79458-P, and BIOGEOEVENTS (CGL2015- 69805-P) of the Spanish Ministry of Economy and Competitiveness (MINECO); by the European Fund for Regional Development (EFRD); by the project "Tectónica Salina en Cinturones Contractivos" (SALTCONBELT-**CGL201785532-P), funded by Agencia Estatal de Investigación (AEI) and **Fondo Europeo de Desarrollo Regional (FEDER); and by projects 2009GR1451 and 2014SGR-467 (GEOMODELS Research Institute and the Grup de Geodinàmica i Anàlisi de Conques), and 2017SGR-824 (SEDIMENTARY GEOLOGY) of the Catalan Government (Departament d'Innovació, Universitats i Empresa). The authors thank Laura Rosell for help in the interpretation of the isotopic analyses of gypsum samples, Policarp Garay Martín for supplying relevant geological documentation in the study area, Alberto Pérez-López and Constantino Benedicto for help during intense field work, Eusebio García for valuable field assistance, and Ramon Salas for fruitful discussions on the Triassic of the northern Valencian Country. Comments by J.D. Martín Martín and one anonymous reviewer significantly improved the manuscript.

\section{REFERENCES}

Alonso-Azcárate, J., Bottrell, S.H., Mas, J.R., 2006. Synsedimentary versus metamorphic control of $\mathrm{S}, \mathrm{O}$ and $\mathrm{Sr}$ isotopic compositions in gypsum evaporites from the Cameros Basin, Spain. Chemical Geology, 234, 46-57.

Álvaro, M., Capote, R., Vegas, R., 1979. Un modelo de evolución geotectónica para la Cadena Celtibérica. Acta Geologica Hispanica, 14, 172-177.

Arche, A., López-Gómez, J., 1996. Origin of the Permian-Triassic Iberian Basin, central-eastern Spain. Tectonophysics, 266, 443-464.

Aurell, M., Meléndez, A., San Román, J., Guimerà, J., Roca, E., Salas, R., Alonso, A., Mas, R., 1992. Tectónica sinsedimentaria distensiva en el límite Triásico-Jurásico en la Cordillera Ibérica. Salamanca, III Congreso Geológico España y VIII Congreso Latinoamericano de Geología, Actas, 1, 50-54.

Bartrina, T., Hernández, E., 1990. Las unidades evaporíticas del Triásico del subsuelo del Maestrazgo. In: Ortí, F., Salvany, J.M ${ }^{\mathrm{a}}$. (eds.). Formaciones evaporíticas de la Cuenca del Ebro y cadenas periféricas, y de la zona de Levante. Empresa 
Nacional de Residuos Radiactivos, S.A.-Universitat de Barcelona, 34-38.

Bernasconi, S.M., Meier, I., Wholwend, S., Brack, P., Hochuli, P.A., Bläsi, H., Wortmann, U.G., Ramseyer, K., 2017. An evaporite-based high-resolution sulfur isotope record of the Late Permian and Triassic seawater sulfate. Geochimica et Cosmochimica Acta, 204, 331-349.

Boulouard, Ch., Viallard, P., 1981. Identification du Ladinien et du Carnien dans les marnes triasiques de la Serranía de Cuenca (Chaîne Ibérique sud occidentale, Espagne): Considérations stratigraphiques et structurales. Bulletin des Centres de Recherche et Exploration-Production. Elf-Aquitaine, 5(1),31-42.

van Buggenum, J.M., 1985. Palynological investigations in the Muschelkalk of Franken (Germany). Stuifmail, 3(3), 8-16.

Brinkmann, R., 1948. Las cadenas béticas y celtibéricas en el SE de España. Traducciones Extranjeras Geología España, 5, 307-434.

Brugman, W.A., Veld, H., Van Buggenum, J.M., Holshuijsen, R.P., Boekelman, W.A., Van den Bergh, J.J., Almekinders, M.P., Poort, R.J., Abbink, O.A., d'Engelbronner, E.R., 1988. Palynological investigations within the Triassic of the Germanic Basin of southern Germany. Stuifmail, 6, 52-54.

Burke, W.H., Denison, R.E., Hetherington, E.A., Koepnick, R.B., Nelson, H.F., Otto, J.B., 1982. Variation of seawater ${ }^{87} \mathrm{Sr} /{ }^{86} \mathrm{Sr}$ throughout Phanerozoic time. Geology, 10, 516-519.

Casanova Honrubia, J.M., Canseco Caballé, M., 2007. Mineralogía de los afloramientos subvolcánicos del término de Torás, Castellón. Revista de Minerales (Asociaciones de Mineralogistas de España), 3(4), 6-15.

Castillo, E., 1980. Síntesis hidrogeológica del Sistema $\mathrm{n}^{\mathrm{o}} 56$. Sierra de Espadán y Plana de Castellón. Instituro Geologico y Minero de España (IGME), Estudios de Gestión y Conservación de Acuíferos, t. 4: Actualización de balances, reevaluación de recursos y reservas, perfeccionamiento del grado de conocimiento, Anejo D, December 1980, 111pp.

Castillo Herrador, F., 1974. Le Trias évaporitique des basins de la Vallée de l'Èbre et de Cuenca. Bulletin Société Géològique France, 16(6), 666-675.

Cortés, J.E., Gómez, J.J., 2016. Middle Jurassic volcanism in a magmatic-rich passive margin linked to the Caudiel Fault Zone (Iberian Range, East of Spain): biostratigraphic dating. Journal Iberian Geology, 42(3), 335-354.

Cortés, J.E., 2018. La arquitectura deposicional de los carbonatos del Jurásico Inferior y Medio relacionados con los materiales volcánicos del sureste de la Cordillera Ibérica. Ph.D. Thesis. Madrid, Universidad Complutense de Madrid, 1272pp.

Claypool, G.E., Holser, W.T., Kaplan, I.R., Sakai, H., Zak, I., 1980. The age curves of sulfur and oxigen isotopes in marine sulfate and their mutual interpretation. Chemical Geology, 28, 199-260.

Doubinger, J., López-Gómez, J., Arche, A., 1990. Pollen and spores from the Permian and Triassic sediments of the Southeastern Iberian Chains, Cueva de Hierro (Cuenca) to Chelva-Manzanera (Valencia-Teruel) region, Spain. Review Palaeobotany Palynology, 66, 25-45.
Dupuy de Lôme, E., 1959. Mapa Geológico de España. Explicación de la Hoja ${ }^{\circ}$ 668, Sagunto (Valencia) a escala 1:50.000. Madrid, Instituto Geologico y Minero de España (IGME).

Dupuy de Lôme, E., Sánchez Lozano, R., 1959. Alumbramiento de aguas subterráneas en Vall de Uxó (Castellón). Madrid, Notas Comunicaciones Instituto Geológico Minero España, 48, 37.

Escudero-Mozo, M.J., Márquez, L., Martín-Chivelet, J., LópezGómez, J., 2012. Foraminíferos anisienses en la Fm. Landete (facies Muschelkalk): Implicaciones bioestratigráficas para la primera transgresión mesozoica en el SE de la Cordillera Ibérica. Geogaceta, 51, 31-34.

Escudero-Mozo, M.J., 2015. Las plataformas carbonáticas del Triásico (facies Muschelkalk) del este de Iberia y Menorca: Implicaciones en la evolución paleogeográfica del oeste del Tethys. Ph.D. Thesis. Madrid, Universidad Complutense de Madrid, 345pp.

Escudero-Mozo, M.J., Márquez-Aliaga, A., Goy, A., MartínChivelet, J., López-Gómez, J., Márquez, L., Arche, A., Plasencia, P., Pla, C., Sánchez-Fernández, D., 2015. Middle Triassic carbonate platforms in eastern Iberia: Evolution of their fauna and palaeogeographic significance in the western Tethys. Palaeogeography, Palaeoclimatology, Palaeoecology, 417, 236-260.

Gallego, M.R., Aurell, M., Bádenas, B., Fontana, B., Meléndez, G., 1994. Origen de las brechas de la base del Jurásico de Leitza (Cordillera Vasco Cantábrica Oriental, Navarra). Geogaceta, 15, 26-29.

Garay Martín, P., 2001. El dominio triásico Espadán-Calderona. Contribución a su conocimiento geológico e hidrogeológico. $\mathrm{Ph} . \mathrm{D}$. Thesis. Universidad de València, microfiche edition, 692pp.

Garay Martín, P., 2005a. Unidades litoestratigráficas del Triásico Medio en el dominio Espadán-Calderona (provincias de Castellón y Valencia). Geo-Temas, 8, 159-162.

Garay Martín, P., 2005b. Rasgos generales del dominio triásico Espadán-Calderona (provincias de Castellón y Valencia). Geo-Temas, 8, 163-166.

Gómez, J.J., Goy, A., 1977. Estudio de las formaciones relacionadas con un montículo de origen volcánico en el Jurásico Medio de Caudiel (Castellón). Oviedo-León, Abstracts VIII Congreso Nacional de Sedimentología, 21.

Gómez, J.J., 1979. El Jurásico en facies carbonatadas del sector levantino de la Cordillera Ibérica. Madrid, Seminarios de Estratigrafía, Serie Monografías, 4, 683pp.

Gómez, J.J., Goy A., 1998. Las unidades litoestratigráficas del tránsito Triásico-Jurásico en la región de Lécera (Zaragoza). Geogaceta, 23, 63-66.

Gómez, J.J., Goy, A., Barrón, E., 2007. Events around the Triassic-Jurassic boundary in northern and eastern Spain: A review. Palaeogeography, Palaeoclimatology, Palaeoecology, 244, 89-110.

Gómez-Gras, D., 1993. El Permotrías de las Baleares y de la vertiente mediterránea de la Cordillera Ibérica y del Maestrat: 
Facies y Petrología Sedimentaria (Parte II). Boletín Geológico y Minero, 104(5), 647-515.

Goy, A., 1995. Ammonoideos del Triásico Medio de España: Bioestratigrafía y Correlaciones. Cuadernos de Geología Ibérica, 19, 21-60.

Goy, A., Gómez, J.J., Yébenes, A., 1976. El Jurásico de la rama castellana de la Cordillera Ibérica (mitad norte): I. Unidades litoestratigráficas. Estudios Geológicos, 32, 391-423.

Guimerà, J., 1987. Precisiones sobre la estructura y la edad de las deformaciones en el área de Llucena-Ribesalbes (prov. Castellón de la Plana). Madrid, Boletín Geológico y Minero, 98(3), 318-334.

Guimerà, J., Mas, R., Alonso, A., 2004. Intraplate deformation in the NW Iberian Chain: Mesozoic extension and contractional Tertiary inversion. London, Journal of the Geological Society, 161, 291-303.

Guimerà, J., 2018. Structure of an intraplate fold-and-thrust belt: The Iberian Chain. A synthesis. Geologic Acta, 16(4), $427-$ 438. DOI: 10.1344/GeologicaActa2018.16.4.6.

Hahne, C., 1943. La cadena celtibérica al E. de la línea de CuencaTeruel-Alfambra. Publicaciones alemanas sobre Geología de España. Madrid, Consejo Superior de Investigaciones Científicas, II, 8-50.

Heunisch, C., 1999. Die Bedeutung der Palynologie für Biostratigraphie und Fazies in der Germanischen Trias. In: Hauschke, N., Wilde, V. (eds.). Trias - eine ganz andere Welt. Pfeil-Verlag (München), Europa am Beginn des Erdmittelalters, 207-220.

Heunisch, C., in press. Palynomorphs of the Muschelkalk. In: Hagdorn, H., Simon, T. (eds.). Stratigraphie von Deutschland XIII. Muschelkalk. Schriftenreihe Deutschen Gessellschaft Geowissenschaften, 91.

Holshuijsen, R.P., 1987. Palynology of the Muschelkalk (Triassic) of Obernsees (FR.G.). Stuifmail, 5(2), 17-22.

IGME, 1973. Memoria y mapa geológico de España a escala 1:50.000. Hoja de Chelva (666). Madrid, Ministerio de Industria, Instituto Geologico y Minero de España (IGME).

IGME, 1974a. Memoria y mapa geológico de España a escala 1:50.000. Hoja de Sagunto (668). Madrid, Ministerio de Industria, Instituto Geologico y Minero de España (IGME).

IGME, 1974b. Memoria y mapa geológico de España a escala 1:50.000. Hoja de Alcora (615). Madrid, Ministerio de Industria, Instituto Geologico y Minero de España (IGME).

IGME, 1974c. Memoria y mapa geológico de España a escala 1:50.000. Hoja de Manzanera (614). Madrid, Ministerio de Industria, Instituto Geologico y Minero de España (IGME).

IGME, 1974d. Memoria y mapa geológico de España a escala 1:50.000. Hoja de Segorbe (640). Madrid, Ministerio de Industria, Instituto Geologico y Minero de España (IGME).

IGME, 1975. Memoria y mapa geológico de España a escala 1:50.000. Hoja de Alpuente (638). Madrid, Ministerio de Industria, Instituto Geologico y Minero de España (IGME).

IGME, 1977. Memoria y mapa geológico de España a escala 1:50.000. Hoja de Jérica (639). Madrid, Ministerio de Industria, Instituto Geologico y Minero de España (IGME).
IGME, 1978. Memoria y mapa geológico de España a escala 1:50.000. Hoja de Camarena de la Sierra (613). Madrid, Ministerio de Industria, Instituto Geologico y Minero de España (IGME).

IGME, 1985a. Memoria y mapa geológico de España a escala 1:200.000. Hoja de Llíria (55). Madrid, Ministerio de Industria, Instituto Geologico y Minero de España (IGME).

IGME, 1985b. Memoria y mapa geológico de España a escala 1:200.000. Hoja de Teruel (47). Madrid, Ministerio de Industria, Instituto Geologico y Minero de España (IGME).

Iríbar, V., Ábalos, B., 2011. The geochemical and isotopic record of evaporite recycling in spas and salterns of the Basque Cantabrian basin, Spain. Applied Geochemistry, 26, 1315-1329.

Jerez Mir, F, 1996. El Trías Betibérico. Una nueva interpetación sobre el Triásico basada en unidades tectosedimentarias. Geogaceta, 20(1), 31-34.

Klimowitz, J., Escalante, S., Hernández, E., Soto, J.I., 2018. La estructuración tectónica alpina del margen occidental del Surco de Valencia (Mediterráneo occidental). Revista Sociedad Geológica España, 31(2), 83-100.

Korte, Ch., Kozur, H.W., Bruckschen, P., Veizer, J., 2003. Strontium isotope evolution of Late Permian and Triassic water. Geochimica et Cosmochimica Acta, 67, 47-62.

Juncal, M., Díez, J.B., de la Jorra, R., Galán-Abelán, B., BorruelAbadía, V., Barrenechea, J.F., Arche, A., López-Gómez, J., 2018. Palynostratigraphy of the Middle Triassic (Anisian) Eslida Formation, SE Iberian Ranges, Spain. Palynology, 42(2), 149-157.

Lanaja, J.M., 1987. Contribución de la exploración petrolífera al conocimiento de la geología de España. Instituto Tecnológico y GeoMinero de España, 465pp.

de Lapparent, A.F., Montardest-Pentecote, L., 1957. Nuevas geológicas entre Cheste y Benagéver (Valencia). Notas Comunicaciones Instituto Geológico Minero España, 47.

López-Gómez, J., Arche, A., 1992. Las unidades litoestratigráficas del Pérmico y Triásico inferior y medio en el sector SE de la Cordillera Ibérica. Estudios Geológicos, 48, 123-143.

López-Gómez, J., Arche, A., 1994. El Triásico y Pérmico del SE de la Cordillera Ibérica. III Coloquio de Estratigrafía y Paleogeografía del Pérmico y Triásico España, Cuenca, Excursion guide-book, 70pp.

López-Gómez, J., Arche, A., Calvet, F, Goy, A., 1998. Epicontinental marine carbonate sediments of the Middle and Upper Triassic in the westernmost part of the Tethys Sea, Iberian Peninsula. Stuttgart, Zentralblatt für Geologie und Paläontologie, 1(9-10), 1033-1084.

López-Gómez, J., Arche, A., Márquez-Aliaga, A., Salas, R., Goy, A., Guimerà, J., Tomás, S., 2005. El Pérmico y Triásico del Desert de les Palmes, Cordillera Ibérica Oriental, Castellón. Cidaris, 27-28, 5-34. IV Coloqiode Estratigrafía y Paleogeografía del Pérmico y Triásico de España, Elche 2005, excursion guide-book, 52pp.

Lucas, S.G., 2017. The Permian and Triassic Chronostratigraphic Scales - Framework for Ordering Events. In: Soto, J.I., Flinch, 
J.F, Tari, G. (eds.). Permo-Triassic salt Provinces of Europe, North Africa and the Atlantic Margins. Elsevier, Tectonic and Hydrocabon Potential, 43-55.

Martín-Martín, J.D., Sanfeliu Montolío, T., Gómez Gras, D., 2005. Mineralogía de arcillas cerámicas. El Permo-Trías de Castelló. VI Premi d'Investigació Consell Social, Castelló de la Plana, Universitat Jaume I, 250pp.

Martín-Martín, J.D., Tritlla, J., Cardellach, E., Gómez-Gras, D., 2006. Tectonically driven fluid flow and associated low-grade metamorphism during the Alpine compression in the eastern Iberian Chain (Spain). Journal of Geochemical Exploration, 89, 267-270.

Martínez-Abad, J.L., 1991. Cuenca del Maestrazgo. Correlación de sondeos I-I'. In: López, F (ed.). Estudio geológico del Maestrazgo y de la mitad meridional de los Catalánides. Informes y Proyectos S.A.-Instituto Geologico y Minero de España (IGME), unpublished.

Nebot, M., 2016. Mesozoic extension and Cenozoic contraction in the Eastern Iberian Chain (Maestrat Basin). Ph.D. Thesis. Barcelona, Universitat de Barcelona, 110pp. Available at: www.tdx.cat/bitstream/10803/403983/1/MNM_PhD_ THESIS.pdf

Nebot, M., Guimerà, J., 2016a. La extensión durante el Pérmico superior-Triásico en el sustrato de la cuenca del Maestrat, y evidencias de tectónica salina en el Muschelkalk medio (Cadena Ibérica Oriental). Geo-Temas, 16, 241-244.

Nebot, M., Guimerà, J. 2016b. Structure of an inverted basin from subsurface and field data: the Late Jurassic-Early Cretaceous Maestrat basin (Iberian Chain). Geologica Acta, 14(2), 155-177.

Ortí, F., 1974. El Keuper del Levante español. Estudios Geológicos, 30, 7-46.

Ortí, F., Vaquer, R., 1980. Volcanismo jurásico del sector valenciano de la Cordillera Ibérica. Distribución y trama estructural. Acta Geologica Hispánica, 15(5), 127-130.

Ortí, F, Pérez-López, A., García-Veigas, J., Rosell, L., Cendón, D.I., Pérez-Valera, F., 2014. Sulfate isotope compositions $\left(\delta^{34} \mathrm{~S}, \delta^{18} \mathrm{O}\right)$ and strontium isotopic ratios $\left({ }^{87} \mathrm{Sr} /{ }^{86} \mathrm{Sr}\right)$ of Triassic evaporites in the Betic Cordillera (SE Spain). Revista Sociedad Geológica España, 27, 79-89.

Ortí, F, Guimerà, J., 2015. Precisiones sobre la litoestratigrafía del Triásico medio y superior en l'Alt Palància (prov. Castelló, Cordillera Ibérica Oriental). In: Jordán Vidal, M.M., Pardo Fabregat, F, Vicente Fortea, A.B. (eds.). Teófilo Sanfeliu Montolio, más allá de la geología. Libro homenaje. Castelló de la Plana, Publicacions de la Universitat Jaume I, Homenatges 2015(4), 109-112.

Ortí, F., Salvany, J.M., Rosell, L., Castelltort, X., Inglès, M., Playà, E., 2018. Middle Triassic evaporite sedimetation in the Catalan basin: Implications for the palaeogeographic evolution in the NE Iberian platform. Sedimentary Geology, 374, 158-178.

Pérez-Arlucea, M., Sopeña, A., 1985. Estratigrafía del Pérmico y Triásico del sector central de la rama castellana de la Cordillera Ibérica (provincias de Guadalajara y Teruel). Cuadernos Geología Ibérica, 41, 207-222.
Pérez-López. A., Solé de Porta, N., Ortí, F, 1996. Facies carbonato-evaporíticas del Trías Superior y tránsito al Lías en el Levante español: nuevas precisiones estratigráficas. Cuadernos Geología Ibérica, 20, 245-269.

Pérez-Valera, J.A., Escudero-Mozo, M.J., Arche, A., Goy, A., López-Gómez, J., Pérez-López, A., Pérez-Valera, F, 2016. Los ammonoideos del Triásico medio de España. Implicaciones bioestratigráficas y paleobiogeográficas. In: Meléndez, G., Núñez, A., Tomás, M. (eds). Actas de las XXXII Jornadas de la Sociedad Española de Paleontología. Instituto Geológico Minero de España, Cuadernos del Museo Geominero, 20, 471-478.

Rambaud, D., 1962. Descripción geológica de la región de Tuéjar (Valencia). Madrid, Boletín Instituto Geológico Minero España, 73, 373-418.

Roca, E., Guimerà, J., 1992. The Neogene structure of the eastern Iberian margin: structural constraints on the crustal evolution of the Valencia trough (western Mediterranean). Tectonophysics, 203, 203-218.

Salas, R., Casas, A., 1993. Mesozoic extensional tectonics, stratrigraphy, and crustal evolution during the Alpine cycle of the eastern Iberian basin. Tectonophysics, 228, 33-55.

Salas, R., Guimerà, J., Mas, R., Martín-Closas, C., Meléndez, A., Alonso, A., 2001. Evolution of the Mesozoic Central Iberian Rift System and its Cainozoic inversion (Iberian Chain). In: Ziegler, P.A., Cavazza, W., Robertson, A.H.F, CrasquinSoleau, S. (eds.). Peri-Tethys Memoir, 6: Peri-Tethyan Rift/ Wrench Basins and Passive Margins. Mémoires du Muséum national d'Histoire naturelle, 186, 145-186.

Salvany, J.M., 2017. Las formaciones yesíferas del Triásico Superior y Jurásico Inferior de Camarasa, en el frente Surpirenaico Catalán. Estudios Geológicos, 73(2), e070.

San Román, J., Aurell, M., 1992. Paleogeographical significance of the Triassic-Jurassic unconformity in the north Iberian basin (Sierra del Moncayo, Spain). Palaeogeography, Palaeoclimatology, Palaeoecology, 99, 101-117.

de Santisteban Bové, C., 2016. La fracturación de la rampa carbonática del tránsito Jurásico Inferior a Medio y volcanismo asociado en el sector de La Salada (Sistema Ibérico, Teruel). Geogaceta, 60, 3-6.

de Santisteban Bové, C., 2018. El volcanismo de la Concòrdia (Llíria, Valencia) y las discontinuidades adyacentes al límite Jurásico Inferior - Jurásico Medio, en el sector Suroriental del Surco Ibérico. Geogaceta, 63, 23-26.

Santos-Cubero, A., de Santisteban Bové, C., Poza Falset, B., 2014. Precisión cronoestratigráfica y sedimentológica del yacimiento icnológico triásico en facies Buntsandstein de Bejís (Castellón, SE de la Cordillera Ibérica). Geogaceta, 56, 103-106.

Solé de Porta, N., Calvet, F., Torrentó, L., 1987. Análisis palinológico del Triásico de los Catalánides (NE España). Cuadernos Geología Ibérica, 11, 237-254.

Sopeña, A., Virgili, C., Arche, A., Ramos, A., Hernando, S., 1983. El Triásico. In: Comba, J. (ed.). Madrid, Instituto Geologico y Minero de España (IGME), Geología de España, 2, 47-64. 
Soto, J.I., Flinch, J.F, Tari, G., 2017. Permo-Triassic basins and Tectonics in Europe, North Africa and the Atlantic Margins: A Synthesis. In: Soto, J.I., Flinch, J.F., Tari, G. (eds.). PermoTriassic salt Provinces of Europe, North Africa and the Atlantic Margins. Elsevier, Tectonic and Hydrocabon Potential, 3-41.

Suárez, J., 2007. La Mancha Triassic and Lower Lias Stratigraphy, a well log interpretation. Journal Iberian Geology, 33(1), 55-78.

Termier, H., Termier, G., 1960. Érosion et sédimentation. Paris, Masson et Cie, 412pp.

Utrilla, R., Pierre, C., Ortí, F., Pueyo, J.J., 1992. Oxygen and sulfur isotope composition as indicators of the origin of the Mesozoic and Cenozoic evaporites from Spain. Chemical Geology, 102, 229-244.
Viallard, P., 1973. Recherches sur le cycle Alpin dans la Chaîne Ibérique sud-occidentale. Université Paul Sabatier, Toulouse, Travaux du Laboratoire de Géologie Méditerranéenne, 445pp. Virgili, C., 1955. El Triásico de los Catalánides. Ph.D. Thesis. Universitat de Barcelona, $942 \mathrm{p}$.

Virgili, C., 1958. El Triásico de los Catalánides. Boletín Instituto Geológico Minero España, 69, 856pp.

Virgili, C., Sopeña, A., Ramos, A., Hernando, S., 1977. Problemas de la cronoestratigrafía del Trías en España. Cuadernos Geología, 4, 57-88.

Wortmann, U.G., Paytan, A., 2012. Rapid Variability of Seawater Chemistry Over past 130 Million Years. Science, 337, 334-336.

\section{Manuscript received April 2019; \\ revision accepted November 2019; \\ published Online February 2020.}




\section{APPENDIX I}

\section{DETAILED DESCRIPTIONS OF STRATIGRAPHIC SECTIONS (S1 TO S16)}

Section coordinates are provided in Figures 6,7 and 8.

\section{Andilla-Bejís outcrop}

Section S1: Overlying the Röt facies, this section (which cross-cuts the Canales to Andilla track near the Andilla village) is comprised of the following formations, units and facies from base to top (Fig. 6): i) Lower Muschelkalk unit, of $82 \mathrm{~m}$ in thickness. This unit is formed by a thin $(16 \mathrm{~m})$ lower carbonate-marl alternation and a carbonate sub-unit $(66 \mathrm{~m})$; ii) Middle Muschelkalk unit, of an original thickness difficult to determine, estimated $>80 \mathrm{~m}$. The unit is comprised of variegated clays and marls, yellowish carbonates, some siltstone and fine-grained sandstones, rare gypsum, and laminated-to-brecciated gypsiferous masses; iii) Upper Muschelkalk unit, at least $77 \mathrm{~m}$ thick. The unit is formed by a carbonate sub-unit $(>66 \mathrm{~m})$ and a thin (about $11 \mathrm{~m}$ ) upper carbonate-marl alternation; iv) Keuper facies, of an original thickness that can be estimated $>60 \mathrm{~m}$. This facies is formed by variegated clays and marls, yellowish carbonate layers, and some gypsum beds. A lower gray unit is distinguished from an upper reddish one; v) Imón Fm., 15-25m thick; and vi) Canales red Claystone unit, $40 \mathrm{~m}$ thick. This unit is made up of red and variegated clays and marls bearing idiomorphic quartz crystals.

Sections S2, S3, S5, S6, S7 and S8: In section S2, which is located to the north of the Canales village (Milvaques house), the upper Muschelkalk unit shows a well-developed upper carbonate-marl alternation. Section S3 is located near the head of the Resinero creek. In section S5, near the Arteas village, a deformed evaporitic succession is observed. In section S6, in a creek of the Arteas river to the west of the Bejís village, the lower Muschelkalk unit can be studied in detail. In section S7, on the road to Bejís in the Palància river, the same deformed evaporitic succession of section S5 is present. In section S8, in the El Molinar site of the Palància river at the NW of Bejís, the lower Muschelkalk unit overlies the Röt facies. In the Resinero block, a similar thickness reduction of both, the lower and the upper Muschelkalk units is observed in a SW to NE direction, i.e. from section S3 near the head of the Resinero creek to the sources of the Palància river at the northeastern end of the block.
Section S8: The carbonate sub-unit of the Molinar section has been initially studied and attributed to the Landete Fm. by López-Gómez et al. (1998). The following aspects in LópezGómez et al. (1998) are highlighted: i) a thickness of about $86 \mathrm{~m}$ was measured; ii) the various members originally defined in the Landete Fm. by López-Gómez and Arche (1992) were identified in this carbonate sub-unit; and iii) an Anisian (early Illyrian) age was assumed based on the finding of an isolated ammonoid specimen attributed to Schreyerites, possibly $S$. abichi. This specimen was the type genus of the early Illyrian according to Mietto and Mafrin (1995). This finding was not cited in Goy (1995). Moreover, in recent studies of this carbonate sub-unit by Escudero-Mozo (2015) and EscuderoMozo et al. (2015), no significant changes are found except the reassignment of this unit to the Cañete Formation with a late Illyrian-Longobardian age. Accordingly, and based on the stratigraphic logging (Fig. 6) and mapping (Fig. 3) together with the palynological data in the present study, the original assignment of the entire Molinar section to the Landete Fm. and an Anisian age proposed by López-Gómez et al. (1998) are here retained.

\section{Almarja outcrop}

Section S4: In the Almarja outcrop, this section shows a Triassic succession which is composed of the following units: top of the Buntsandstein facies (red sandstones and the overlying Röt facies); lower Muschelkalk unit (lower carbonate-marl alteration; carbonate sub-unit) and middle Muschelkalk unit.

\section{Torás outcrop}

The Triassic succession in the small Torás outcrops is composed of the uppermost part of the Buntsandstein sandstone and the overlying Röt facies, and by the lower and the middle Muschelkalk units. The middle Muschelkalk unit consists of variegated claystone, marl, and gypsum beds severely deformed, which include large ophitic (doleritic) masses (Casanova Honrubia and Canseco Caballé, 2007).

\section{Caudiel outcrop}

Section S9: At the south of the domal anticline, a section of the upper Muschelkalk unit can be observed in detail along the ancient railway cut of the Sierra Menera company (currently adapted as a cycling/trekking path) to the east of the Masadas Blancas site (Fig. 7). This is an uncomplete section because its base and top are covered. 
Section S10: A simplified stratigraphic section (S10) across the domal structure in the central part of the outcrop is shown in Figure 7. The K5 unit of the Keuper facies is present as a thick, white mass of severely deformed laminated gypsum in the northwestern part of the domal anticline, far from this section. In this outcrop, the presence of a $20-25$ m thick alternation made up of yellowish marls and dolomitic limestones overlying the carbonate sub-unit of the lower Muschelkalk unit has been cited by Castillo (1980) (in Garay Martín, 2001) in the Cerro Negro located about $5 \mathrm{~km}$ to the NNW of Caudiel. This alternation grades upwards into $15-20 \mathrm{~m}$ of marls and variegated claystones with euhedral quartz crystals assigned to the middle Muschelkalk unit.

\section{Montán outcrop}

Section S11: This section in the Cueva Cirat (a huge cave to the SW of Montán) shows a lower Muschelkalk succession that rests on the Röt facies. The succession is affected by faulting. The carbonate sub-unit of the Muschelkalk facies in the Cueva Cirat section (Fig. 7) was studied by Garay Martín (2001), who assigned this section (65m thick) to the lower Muschelkalk. It was later studied by Escudero-Mozo et al. (2012), who measured a thickness of about $55 \mathrm{~m}$ and assigned this sub-unit to the Landete Formation. This stratigraphic placement is based on the identification of late Anisian foraminiferal associations at the base of this sub-unit. The same section was reassigned to the Cañete Formation by Escudero-Mozo (2015) and Escudero-Mozo et al. (2015), despite no ammonoidea specimens were found. In section $\mathrm{S} 11$ of this study, $71 \mathrm{~m}$ thick, the palynological assemblages indicate an Anisian age of the lower alternation, and the facies succession in the overlying carbonate sub-unit is identical to that in other sections of the lower Muschelkalk unit studied. Therefore, the original assignment to the Landete Formation (Oronet Formation of Garay Martín, 2001) is here retained.

Section S12 (composite): The carbonate sub-unit of the upper Muschelkalk unit crops out along the CaudielMontanejos road in two major portions (portions ' $a$ ' and ' $b$ ' of section S12, respectively). These portions can be correlated by a key-bed. This is a $60-70 \mathrm{~cm}$ thick marly limestone bed, very fine-grained and light grey-green color, located towards the base of this carbonate sub-unit. The lower carbonate-marl alternation of this upper Muschelkalk unit is shown in section $12 b$ to the SW of Montán (Fig. 2).

Section S13: Parallel to the Montán composite section, the Plano section (S13) along the creek in the 'Fuente del Plano' (a source on the road to Torralba del Pinar village) shows a complex tectonic structure of faults and thrusts involving the lower and the upper Muschelkalk units (Fig. 8).

Section S14: This almost complete section of the lower Muschelkalk unit is present in a track which begins in the K.10 of the Barracas to Fuente la Reina road (about $2 \mathrm{~km}$ before arriving to Fuente la Reina) and goes to the SE passing by the La Pinosa source (Fig. 8).

Sections S15 and S16: These sections, at the south and the north of the Pina de Montalgrao village respectively, show successions of the middle and upper Muschelkalk units and the Imón Fm. (Fig. 8). 